\title{
Evidence for a systemic embryotoxic effect of early luteal regression in the ewe
}

\author{
Beth Alyson Costine \\ West Virginia University
}

Follow this and additional works at: https://researchrepository.wvu.edu/etd

\section{Recommended Citation}

Costine, Beth Alyson, "Evidence for a systemic embryotoxic effect of early luteal regression in the ewe" (2000). Graduate Theses, Dissertations, and Problem Reports. 1124.

https://researchrepository.wvu.edu/etd/1124

This Thesis is protected by copyright and/or related rights. It has been brought to you by the The Research Repository @ WVU with permission from the rights-holder(s). You are free to use this Thesis in any way that is permitted by the copyright and related rights legislation that applies to your use. For other uses you must obtain permission from the rights-holder(s) directly, unless additional rights are indicated by a Creative Commons license in the record and/ or on the work itself. This Thesis has been accepted for inclusion in WVU Graduate Theses, Dissertations, and Problem Reports collection by an authorized administrator of The Research Repository @ WVU. For more information, please contact researchrepository@mail.wvu.edu. 


\title{
EVIDENCE FOR A SYSTEMIC EMBRYOTOXIC EFFECT OF EARLY LUTEAL REGRESSION IN THE EWE.
}

\author{
Beth A. Costine \\ Thesis submitted to \\ The College of Agriculture, Forestry and Consumer Sciences \\ at West Virginia University \\ in partial fulfillment of the requirements \\ for the degree of \\ Master of Science \\ in \\ Reproductive Physiology \\ Dr. E. Keith Inskeep, Ph.D., Chair \\ Dr. Robert A. Dailey, Ph.D. \\ Dr. Paul E. Lewis, Ph.D. \\ Department of Animal and Veterinary Sciences \\ Morgantown, West Virginia \\ 2000
}

Key words: Corpus Luteum, Ewes, Prostaglandin, Embryo 


\title{
ABSTRACT \\ Evidence for a systemic embryotoxic effect of early luteal regression in the ewe.
}

\begin{abstract}
Beth A. Costine
Experiments were performed to determine if a short-lived corpus luteum was embryotoxic in ewes given supplemental progesterone and the route of transfer of embryotoxic products. Mated ewes were lutectomized or sham lutectomized on day 4 after estrus. Following surgery, ewes received saline or $\mathrm{PGF}_{2 \alpha}$ through days 6 or 7. Pregnancy rate was reduced after treatment with $\mathrm{PGF}_{2 \alpha}(\mathrm{P}<0.001)$ compared to controls and was increased in $\mathrm{PGF}_{2 \alpha}$-treated ewes by lutectomy $(\mathrm{P}<0.05)$. Mated ewes with bilateral ovulations were unilaterally lutectomized, and each uterine horn was ligated to eliminate intercornual flow on day 4 after estrus. Treatment with $\mathrm{PGF}_{2 \alpha}$ on day 5 through 8 reduced pregnancy rates $(\mathrm{P}<0.01)$, but embryonic survival did not differ in the uterine horns ipsilateral or contralateral to the regressing CL. The regressing CL is embryotoxic in progesterone-supplemented ewes, and embryotoxic luteal products have been shown to act by non-local pathways.
\end{abstract}




\section{ACKNOWLEDGEMENTS}

I would like to express my gratitude to my family for their involvement in my early animal husbandry aspirations, and for their continued encouragement and support. I would like to thank my mom for not letting my teachers at school be my only educators. Kindergarten through high school she was my private tutor and library. I would like to thank my dad for teaching me responsibility and for giving me biceps. Life would be dull without my brother who taught me how to have fun while doing anything. My "Grammie Costine" not only made my education financially possible, but also is an inspiration by being an educated woman - before it was hip.

I am indebted to Dr. Greg Lewis and Dr. Meghan Wulster-Radcliffe for introducing me to research. Meghan spent a great deal of time teaching me the basics and gave me an excellent example to follow.

I would like to thank Dr. Brian Sayre for his direction and instruction. I would like to thank Marlon Knights for his assistance with ultrasounding, and Jason Candler, Ida Holaskova, TD Maze, and Melanie Starbuck for their help with surgeries. I would also like to thank Dr. Phil Bridges, Dr. Rob Taft, and Dr. Matt Wilson for their scientific discussions and their willingness to answer my questions. This research would not have been possible without the faithfulness of my work-studies: Autumn Iwanonkiw, Amy Varner, Winnie Massett, April Snyder, and Scott Moore.

My gratitude is also extended to the WVU farm crew especially to Andy Holt who was always ready to accommodate my need to rearrange sheep like most woman rearrange furniture. I would also like to thank the FARF crew, Sarah Beamer and Karrie Miller, for their assistance and for their vigilant care of my recovering ewes. 
Finally, I would like to thank Drs. Dailey, Inskeep, and Lewis who spend as much time in the field as they do in school. Their involvement in journal clubs, seminars, and class is invaluable. I would especially like to thank Dr. Inskeep for his enthusiasm, as demonstrated by the tackling of sheep I let by me, for his open-door policy, for his guidance in the interpretation of the literature, and for his patience while teaching me to write. 


\section{TABLE OF CONTENTS}

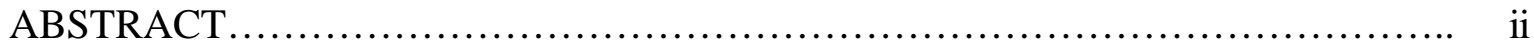

ACKNOWLEGEMENTS .......................................................

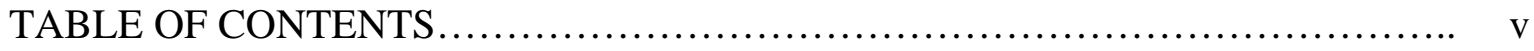

LIST OF TABLES............................................................ vii

LIST OF FIGURES ......................................................... viii

INTRODUCTION............................................................. 1

REVIEW OF LITERATURE................................................. 3

Characterization of abbreviated luteal phases.............................. 3

Uterine secretion of prostaglandin................................. 3

Uterine receptors and the role of oxytocin......................... 5

The corpus luteum............................................... 9

Utero-ovarian relationships: local vs. systemic............................ 12

The utero-ovarian vascular system................................. 12

The effect of the ovary on the uterus.............................. 16

The effect of the ovary on the ovary............................... 17

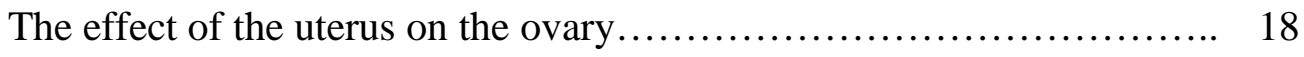

Uterine contractility .................................................. 21

The embryotoxic factor. ................................................ 23

STATEMENT OF THE PROBLEM................................................ 27

MATERIALS AND METHODS ................................................ 29

Experiment 1) Effects of $\mathrm{PGF}_{2 \alpha}$ or saline plus lutectomy or sham surgery

on pregnancy rate ewes.................................................. 29

Experiment 2) Effects of $\mathrm{PGF}_{2 \alpha}$ or saline plus unilateral lutectomy on embryonic survival in the isolated uterine horn ipsilateral or contralateral to the $\mathrm{CL}$ in ewes. 


\section{TABLE OF CONTENTS (Cont.)}

RESULTS............................................................. 34

Experiment 1 pregnancy rates....................................... 34

Experiment 2 pregnancy rates....................................... 35

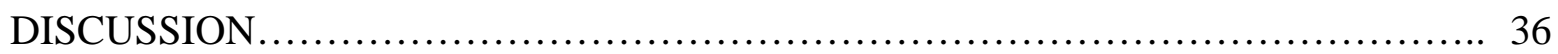

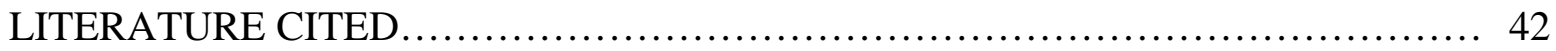

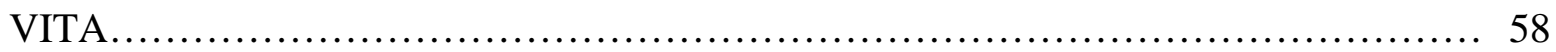




\section{LIST OF TABLES}

$1 \quad$ Pregnancy rates of ewes treated with $\mathrm{PGF}_{2 \alpha}$ or saline receiving complete lutectomy or sham surgery (Experiment 1)...................... 34

$2 \quad$ Pregnancy rates by uterine horns in ewes treated with saline or $\mathrm{PGF}_{2 \alpha}$ (Experiment 2).............................................. 35

3 Frequency of ewes with one or two embryos after treatment with saline or $\mathrm{PGF}_{2 \alpha}$ in ewes that ovulated once on each ovary and had one CL removed (Experiment 2)............................................ 36 


\section{LIST OF FIGURES}

Figure $\quad$ Page

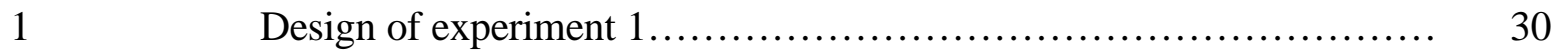

2

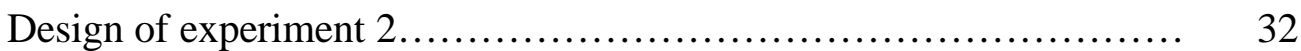




\section{INTRODUCTION}

Resumption of follicular development, estrus, and first ovulation in postpartum cows usually does not result in a successful pregnancy (Ward et al., 1979; Odde et al., 1980). The luteal phase following first ovulation is characterized by spontaneous early regression of the corpus luteum (CL; Odde et al., 1980). Attempts to supplement the sub-functional or regressing CL with exogenous progesterone failed to increase pregnancy rates (Wiltbank et al., 1956; Breuel et al., 1993). Progesterone treatment prior to the first ovulation in the postpartum cow prevented premature luteal regression and increased pregnancy rates (Ramirez-Godinez et al., 1981).

A short-lived CL during the resumption of reproductive activity is common in ewes after seasonal anestrus. Concentrations of progesterone were elevated for only 4 to 8 days after induced ovulation following ram introduction (Knight et al., 1981). The early-regressing CL usually is followed by a normal-lived CL (Keisler et al., 1983).

The requirement of progesterone pretreatment for embryonic survival emphasizes the role of progesterone in regulating the timing of uterine secretion of prostaglandin $(\mathrm{PG}) \mathrm{F}_{2 \alpha}$, which causes regression of the CL. The luteal phase is of normal length, and maternal recognition of pregnancy can occur, when uterine secretion of $\mathrm{PGF}_{2 \alpha}$ remains low until days 12 to 13 in the ewe or days 14 to 17 in the cow. Hysterectomy after ovulation prevented the early regression of the corpus luteum in the ewe (Keisler et al., 1983) and the cow (Copelin et al., 1987). First exposure of the uterus to progesterone results in heightened secretion of $\mathrm{PGF}_{2 \alpha}$ early in the luteal phase and subsequent early luteal regression (Cooper et al., 1991).

However, the cause of low fertility in postpartum cows is multifaceted. Inhibition of prostaglandin secretion alone was not sufficient to improve pregnancy rates in postpartum cows 
supplemented with progesterone, but removal of the corpus luteum in combination with inhibition of prostaglandin secretion was sufficient for normal pregnancy rates (Buford et al., 1996). The presence of the early-regressing CL was detrimental to embryonic survival in spite of progesterone supplementation. Likewise, treatment of cows or ewes with normal estrous cycles with $\mathrm{PGF}_{2 \alpha}$ every eight hours on days 4 through 7 or 5 through 8 decreased pregnancy rates despite concomitant progesterone replacement therapy (Buford et al., 1996). Normal pregnancy rates were restored in such animals by lutectomy prior to treatment with $\mathrm{PGF}_{2 \alpha}$ (Buford et al., 1996). Thus, the short-lived CL had an embryotoxic effect in both pregnant postpartum cows and in pregnant cows treated with $\mathrm{PGF}_{2 \alpha}$ to induce early luteal regression. The location of the embryo in relation to the short-lived CL did not alter the rate of survival of embryos transferred into cows induced to have shortened luteal phases (Hernandez-Fonseca et al., 1998). The embryotoxic factor(s) produced from the regressing CL appeared to equally affect embryos despite their uterine location in relation to the CL, and was therefore considered to be systemically circulated. This conclusion is in contrast to the local utero-ovarian relationship observed in cows and ewes during the normally timed luteal regression.

The physiological differences in cows expected to have short or normal length luteal phases and the anatomy of the utero-ovarian vasculature will be discussed. Studies designed to determine whether the uterine lumen is part of the route of transfer of the embryotoxic components from the short-lived CL to the contralateral embryo will be presented. These data should aid in our understanding of this physiological process. 


\section{REVIEW OF LITERATURE}

\section{Characterization of abbreviated luteal phases}

A CL of normal life span requires adequate luteotropins, proper timing of the luteolytic signal, and the sensitivity to respond appropriately to these signals. Investigation of luteal and uterine differences between animals with normal and shortened luteal phases may lead to the identification of candidates for the embryotoxic factor(s) produced during early luteal regression.

\section{Uterine secretion of prostaglandin}

The distinguishing characteristic between cows or ewes expected to have a luteal phase of short or normal length is the lack of uterine exposure to progesterone prior to formation of the CL. Untimely progesterone exposure, such as at the beginning of the estrous cycle, will shorten the luteal phase (Lewis et al., 1968). Administration of progesterone 8 hours after the onset of estrus resulted in an earlier initial rise of $\mathrm{PGF}_{2 \alpha}$ (day 8 vs. day 12; Ottobre et al., 1980).

The role of $\mathrm{PGF}_{2 \alpha}$ as the major cause of the short-lived CL was established further by Keisler et al. (1983) in the ewe lamb reaching puberty by Copelin et al. $(1989,1987)$ in the cow. These workers were able to prevent a short-lived CL in the ewe lamb by hysterectomy and in the postpartum cow by hysterectomy or by active immunization against $\mathrm{PGF}_{2 \alpha}$. Early-weaned postpartum cows with short estrous cycles had higher mean concentrations of $\mathrm{PGF}_{2 \alpha}$ on days 4

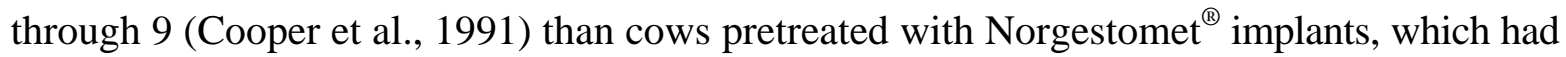
normal estrous cycles. In the norgestomet-pretreated cows, concentrations of $\mathrm{PGF}_{2 \alpha}$ during 
progestogen exposure mimicked those of non-treated cows after induced ovulation (Cooper et al., 1991). Although both groups of cows experienced increases in $\mathrm{PGF}_{2 \alpha}$, cows pre-treated with progestogen exhibited this rise during treatment, before CL formation. Increases in peripheral concentrations of 15 keto, 13,14 dihydro-prostaglandin $\mathrm{F}_{2 \alpha}$ (PGFM, the major metabolite of PGF 2 ${ }_{\alpha}$ ) were not observed consistently in beef cows with short-lived CL (Cooper et al.,1991), but were observed during the interovulatory period in dairy cows with short luteal phases (Peter et al., 1989).

The ratio of $\mathrm{PGF}_{2 \alpha}$, a luteolytic prostaglandin, to $\mathrm{PGE}_{2}$ and $\mathrm{PGI}_{2}$, luteotropic prostaglandins, was compared in endometrial tissue from postpartum cows expected to have a normal or short-lived CL. Luteotropic prostaglandins are required for luteal development and early luteal maintenance (Milvae and Hansel, 1985). Day-5 endometrial explants from postpartum cows expected to have a short luteal phase contained higher overall concentrations of $\mathrm{PGF}_{2 \alpha}$, $\mathrm{PGE}_{2}$, and 6-keto- $\mathrm{PGF}_{1 \alpha}$ (the stable metabolite of $\mathrm{PGI}_{2}$ ) than day-5 explants from cows expected to have normal length luteal phase (Zollers et al., 1991). Treatment with arachidonic acid and oxytocin resulted in greater increases in secretion of $\mathrm{PGF}_{2 \alpha}$ by endometrial explants taken from cows with short estrous cycles than by explants from cows with normal estrous cycles. The ratios of $\mathrm{PGF}_{2 \alpha}$ to 6-keto- $\mathrm{PGF}_{1 \alpha}$ and $\mathrm{PGE}_{2}$ were higher in explants from cows with short estrous cycles (Zollers et al., 1991). Thus the uterus of the animal with a shortened estrous cycle was not only hyperactive in secretion of luteolysins, but also deficient in secretion of luteotropic prostaglandins. 


\section{Uterine receptors and the role of oxytocin}

High concentrations of estrogen are thought to be crucial for the establishment of the population of progesterone receptors in the uterine endometrium for the subsequent luteal phase. Norgestomet-pretreated postpartum cows had higher follicular concentrations of estradiol-17 $\beta$ at estrus compared to untreated postpartum cows (Garcia-Winder et al., 1987). Concentrations of

progesterone receptors are highest during estrus and decline throughout the luteal phase (Rexroad et al., 1981a). Treatment with estrogen increased the number of uterine progesterone receptors in ovariectomized ewes, while treatment with progesterone suppressed the number of progesterone receptors (Rexroad et al., 1981b). Thus it appears that progesterone receptors are formed due to either high concentrations of estrogen or lack of progesterone. Based upon the decline in concentration of receptors and reduced binding of progesterone after treatment with progesterone, it has been proposed that progesterone receptors are down-regulated by progesterone throughout the subsequent luteal phase. Indeed, progesterone administered on day 0 or 1 of the estrous cycle advanced the time of increased secretion of $\mathrm{PGF}_{2 \alpha}$ (Ottobre et al., 1980) and luteal regression (Lewis et al., 1968) presumably by advancing the down-regulation of uterine progesterone receptors (Rexroad et al., 1981b). Alternatively, uterine timing of secretion of $\mathrm{PGF}_{2 \alpha}$ may be dependent upon whether prostaglandin synthetic enzymes were induced by progesterone exposure in the early luteal phase or in a previous luteal phase.

In studies of patterns of secretion of $\mathrm{PGF}_{2 \alpha}$ in ewes ovariectomized on day 9, ovarian steroids after day 9 had minimal influence on the timing of initial increases of uterine secretion of $\mathrm{PGF}_{2 \alpha}$ (Ottobre et al., 1984). Ottobre et al. (1984) and Vincent and Inskeep (1986) went on to show that ovariectomy on day 12 or 14 was followed by final increases in $\mathrm{PGF}_{2 \alpha}$, similar to those 
seen after decreases in concentrations of progesterone during luteal regression. In contrast, replacement therapy with progesterone kept secretion of $\mathrm{PGF}_{2 \alpha}$ in the mid-range that preceded luteolysis.

Postpartum cows with short luteal phases had lower concentrations of endometrial progesterone receptors on day 5 than cows pretreated with norgestomet (Zollers et al., 1993). Lower concentrations of estrogen at estrus in postpartum cows may yield an inadequate number of endometrial progesterone receptors, thus setting the earlier timing of secretion of $\mathrm{PGF}_{2 \alpha}$. The incidence of short cycles in postpartum cows was reduced by estradiol implants, in cows that ovulated prior to implant removal (Day et al., 1990). The induction of estrogen receptors and the ability of the follicle to secrete estrogen also may depend on the priming effect of progesterone.

LH receptors have been isolated on bovine endometrium (Freidman et al., 1995) and in uterine veins (Shemesh et al., 1997). Activation of the endometrial receptors resulted in an increase in concentrations of cycloxygenase $(\mathrm{COX})$, a rate-limiting enzyme in prostaglandin synthesis, subsequent secretion of $\mathrm{PGF}_{2 \alpha}$, and down regulation of the $\mathrm{LH}$ receptor (Freidman et al., 1995). As expected if $\mathrm{LH}$ plays a role in secretion of $\mathrm{PGF}_{2 \alpha}$, the concentrations of $\mathrm{LH}$ receptors in the endometrium were highest on days 15 to 17 . However, numbers of LH receptors were equally as high on days 2 to 4 and absent during all other stages, including during the time of structural luteal regression (days 18 to 20; Freidman et al., 1995). Basal expression of COX was three-fold higher during days 15 to 17 , but LH-stimulated COX expression was increased equally in endometrium from days 2 to 4 and 15 to 17 (Freidman et al., 1995). LH receptors were expressed in the uterine vein only during proestrus and activation by $\mathrm{LH}$ increased COX-2 expression and subsequently induced secretion of both $\mathrm{PGF}_{2 \alpha}$ and $\mathrm{PGE}_{2}$ (Shemesh et al., 1997). 
LH receptors in the endometrium may play an important role in the initiation of normal luteal regression.

Oxytocin was first implicated in luteal function by Armstrong and Hansel (1959). Chronic treatment of heifers with oxytocin, beginning on the day of estrus and ending between days 7 to 15, shortened the luteal phase, and this effect was eliminated by hysterectomy (Armstrong and Hansel, 1959). Day-7 CL from heifers treated with oxytocin were smaller than CL from untreated heifers, which was interpreted as an inhibition of normal luteal development (Armstrong and Hansel, 1959). Oxytocin is produced during the process of luteinization (Voss and Fortune, 1992) and is present in the CL of ewes (Wathes and Swann, 1982) and cows (Fields, et al., 1983). Luteal release of oxytocin has been found to be concomitant with peaks of PGFM (Peter et al., 1989; Fairclough et al., 1980; Cooper et al., 1991). Oxytocin receptors are present in the endometrium and increase gradually in concentration as the luteal phase progresses (Roberts et al., 1976). These disparate observations have stimulated much research that has attempted to establish a cause and effect relationship between oxytocin and $\mathrm{PGF}_{2 \alpha}$ (reviewed by McCracken et al., 1999). However, depletion of luteal oxytocin did not impede luteolysis (Kotwica and Skarzynski, 1993; McCracken et al., 2000).

In ovariectomized ewes pretreated with progesterone and estrogen, administration of oxytocin stimulated secretion of $\mathrm{PGF}_{2 \alpha}$ (Sharma and Fitzpatrick, 1974). However, in intact ewes, oxytocin failed to elicit increased secretion of $\mathrm{PGF}_{2 \alpha}$ until late in the luteal phase when progesterone had already begun to decline (Fairclough et al., 1984). Oxytocin receptors gradually increased in concentration in the endometrium as the luteal phase progressed (Roberts et al., 1976). Oxytocin has been found to act through a 7-transmembrane G-protein-linked receptor on 
endometrial cells and to activate the protein kinase $\mathrm{C}$ second messenger system. In ovariectomized ewes treated with estradiol, hydrolysis of phosphoinositide and subsequent formation of inositol triphosphate resulted in an increase in intracellular calcium, activation of phospholipase $\mathrm{A}_{2}$, and conversion of phosphoinositides to diacylglycerol, stimulating release of arachidonic acid, the rate-limiting precursor of $\mathrm{PGF}_{2 \alpha}$ synthesis (Flint et al., 1986). Estradiol may enhance the ability of oxytocin to induce secretion of $\mathrm{PGF}_{2 \alpha}$ by increasing the activity of phospholipase $\mathrm{A}_{2}$ (Bonney et al., 1987).

Cows with short estrous cycles appear to have an altered response to oxytocin and may have altered oxytocin secretion. On day 5 of the estrous cycle, cows expected to have a short luteal phase had a higher concentration of endometrial oxytocin receptors than cows expected to have a luteal phase of normal length (Zollers et al., 1993). Both baseline and peak concentrations of oxytocin were elevated in dairy cows with shortened estrous cycles (Peter et al., 1989), but Cooper et al. (1991) did not find consistent rises in oxytocin in association with elevated $\mathrm{PGF}_{2 \alpha}$ in beef cows with short luteal phases.

Animals with shortened estrous cycles may have a heightened sensitivity to oxytocin that makes them more susceptible to structural luteal regression. In animals with estrous cycles of normal length, dosages of $\mathrm{PGF}_{2 \alpha}$ that would be luteolytic later in the cycle caused a transient decline in progesterone production when given early in the cycle. Thus it appeared that the CL has the ability to overcome functional luteolysis (Beal et al., 1980). Cows or ewes with shortened estrous cycles may have a longer duration of secretion of $\mathrm{PGF}_{2 \alpha}$ in response to oxytocin during structural regression. Although Zollers et al. (1989) found similar increases in PGFM during the first two hours after an oxytocin challenge in cows with short and normal luteal phases, 
concentrations of PGFM remained higher longer, until the end of the sampling period at four hours, in animals with short estrous cycles. Mirando et al. (1990) measured the ability of oxytocin to stimulate incorporation of tritiated inositol into inositol triphosphate (IP3) in pregnant and nonpregnant ewes. It appeared that the ability of oxytocin to stimulate the second messenger system was decreased markedly in the pregnant ewes. Pregnant ewes had a lower basal turnover of IP3 and total inositol phosphate on day 16 than nonpregnant ewes.

In swine, Ludwig et al. (1998) found that endometrial responsiveness to oxytocin was not regulated solely by concentrations of oxytocin receptors. In cyclic gilts, stimulation of hydrolysis of phosphoinositide (PI) by aluminum fluoride (a G-protein stimulator) did not differ throughout the cycle, but oxytocin-stimulated hydrolysis of PI increased as the cycle progressed. Oxytocin stimulated phosphoinositide did not differ throughout the cycle in pregnant gilts. Regulation of oxytocin stimulation may occur at two levels: 1) receptor coupling to G protein and/or 2) amount of activation of protein kinase $\mathrm{C}$. Therefore, differential regulation of the ability of the oxytocin receptor to elicit an intracellular response may be a mode by which the endometrium of the animal with a shortened estrous cycle is able to augment the secretion of $\mathrm{PGF}_{2 \alpha}$.

\section{The corpus luteum}

During normally-timed luteal regression, it is hypothesized that the CL secretes $\mathrm{PGF}_{2 \alpha}$ in response to uterine $\mathrm{PGF}_{2 \alpha}$, thus contributing to its own demise. Resistance to $\mathrm{PGF}_{2 \alpha}$ by young CL of cows is thought to be mediated by decreased expression of prostaglandin synthetic enzymes (Tsai and Wiltbank, 1998). In cows expected to have normal length luteal phases, a single $25 \mathrm{mg}$ injection of $\mathrm{PGF}_{2 \alpha}$ will regress a day-11 CL, but not a day-4 CL (Tsai and Wiltbank, 1998). The 
lack of responsiveness in the day-4 CL is not due to a reduction or absence of $\mathrm{PGF}_{2 \alpha}$ receptors on the CL (Wiltbank et al., 1995). In both day-4 and day-11 CL, the 7-transmembrane receptor transcript decreased after the single $\mathrm{PGF}_{2 \alpha}$ treatment. Thus $\mathrm{PGF}_{2 \alpha}$ reached the early $\mathrm{CL}$, bound to the receptors, and induced alterations in gene expression. Four hours after treatment with $\mathrm{PGF}_{2 \alpha}$, concentrations of COX-2 transcript, the rate limiting enzyme in prostaglandin synthesis, were decreased in day-4 CL, but COX-2 was increased over three-fold in day-11 CL. Down-regulation of $\mathrm{PGF}_{2 \alpha}$ synthetic enzymes may enable day-4 CL to be resistant to a $\mathrm{PGF}_{2 \alpha}$ challenge.

In response to $\mathrm{PGF}_{2 \alpha}$, the secretion of $\mathrm{PGF}_{2 \alpha}$ by the short-lived CL is different from that by a non-regressing CL of the same age. Day-6 short-lived CL had higher basal concentrations of $\mathrm{PGF}_{2 \alpha}, \mathrm{PGI}_{2}$, and $\mathrm{PGE}_{2}$ than normal day-6 CL (Hu et al., 1990). Stimulation with calcium ionophore (which mimics the second messenger of the intracellular signaling cascade of $\mathrm{PGF}_{2 \alpha}$ ) significantly increased secretion of $\mathrm{PGF}_{2 \alpha}$ in short-lived CL, but not in non-regressing CL (Hu et al., 1990). In addition, the luteotropins $\mathrm{PGI}_{2}$ and $\mathrm{PGE}_{2}$ increased significantly in response to calcium ionophore in normal CL, but not in short-lived CL. Thus there were higher ratios of $\mathrm{PGI}_{2}: \mathrm{PGF}_{2 \alpha}$ and $\mathrm{PGE}_{2}: \mathrm{PGF}_{2 \alpha}$ in normal-lived CL (Hu et al., 1990). Therefore, short-lived CL may be not only more susceptible to effects of $\mathrm{PGF}_{2 \alpha}$ to stimulate gene transcription for prostaglandin synthetic enzymes, but also may secrete more luteolytic than luteotropic prostaglandins.

Despite the previous data, it is not clear whether the CL expected to regress early is inherently more sensitive to $\mathrm{PGF}_{2 \alpha}$. Hysterectomized cows that were pre-treated with norgestomet or received no pre-treatment had an equal response in concentrations of progesterone after a single injection of $\mathrm{PGF}_{2 \alpha}$ (Copelin et al., 1988). However, the 
hysterectomies were performed before the CL would be exposed to heightened concentrations of $\mathrm{PGF}_{2 \alpha}$ from the uterus. Changes in the ability of the CL to synthesize $\mathrm{PGF}_{2 \alpha}$ may be dependent on the uterus. Indeed, chronic treatment (15 mg every 8 hours) of cows with $\mathrm{PGF}_{2 \alpha}$, beginning on day 4 , induced an increase in the expression of luteal PGF receptors, beginning 24 hours after initiation of treatment and lasting until 72 hours after treatment (Sayre et al., 2000). Expression of COX-2 and prostaglandin $\mathrm{F}_{2 \alpha}$ synthase was increased after the first injection of $\mathrm{PGF}_{2 \alpha}$ and remained elevated throughout the treatment period. Chronic exposure of the CL to $\mathrm{PGF}_{2 \alpha^{-}}$ induced different alterations in gene expression compared to a single treatment. Chronic secretion of $\mathrm{PGF}_{2 \alpha}$ from the uterus may elevate luteal prostaglandin synthetic enzymes, which can then increase the total amount of $\mathrm{PGF}_{2 \alpha}$ acting on the CL.

Chronic administration of $\mathrm{PGF}_{2 \alpha}$ on days 4 through 7 in the cow resulted in an increased luteal production of IGFBP-1 compared to cows treated with saline (Sayre et al., 2000). IGFBP1 is thought to decrease the availability of IGF-1, which is a luteotropin, as defined by ability to increase synthesis of progesterone (McArdle et al., 1989). IGF-1 increased throughout the luteal phase, then declined during luteal regression (Einspanier et al., 1990). Sayre et al. (2000) proposed that luteal IGFBP-1 may have intraluteal effects on secretion of progesterone.

The ability of the CL to metabolize $\mathrm{PGF}_{2 \alpha}$ may affect the sensitivity of the CL to uterine $\mathrm{PGF}_{2 \alpha}$. The activity of 15-hydroxyprostaglandin dehydrogenase (PGDH), the rate limiting enzyme in the inactivation of prostaglandins of the F series to PGFM, was higher in both day-4 CL and day-13 pregnant CL compared to the day-13 CL of the estrous cycle in ewes (Silva et al., 2000). In contrast to previous studies in cows (Tsai and Wiltbank, 1998), the day-4 CL of the ewe had a higher amount of COX-2 mRNA than the day-13 pregnant CL (Silva et al., 2000). On 
day 13 of the estrous cycle, when COX-2 mRNA was found previously to be the highest in the cow CL (Tsai and Wiltbank, 1998), COX-2 mRNA was undetectable in the ewe CL (Silva et al., 2000). The role of the ability of the CL to metabolize prostaglandins has not been determined in a CL that is expected to be of short life-span.

\section{Utero- ovarian relationships: local vs. systemic}

A local utero-ovarian relationship is one in which the uterus and ovaries can affect each other directly. The result of a local utero-ovarian relationship is observed when an ovary has an effect on the adjacent uterine horn that it does not have on the opposite uterine horn, or the uterine horn affects the adjacent ovary differentially. A systemic relationship involves the circulatory system, and one ovary does not have a greater effect on the adjacent uterine horn or one uterine horn does not differentially affect the adjacent ovary. However, a relationship measured by an endpoint of pregnancy or luteal regression may appear to be systemic because of the ability of substances to travel between uterine horns (by the uterine lumen or by vasculature connecting the horns), even though general systemic circulation is not involved.

\section{The utero-ovarian vascular system}

The existence of local or systemic relationships has been shown by both anatomical and physiological observations. The utero-ovarian vasculature of many species was examined by Ginther (1976). Among the farm species, sheep, cows and swine have the potential for local utero-ovarian relationships as evidenced by the extensive contact between the arterial and venous 
vessels. The uterus and the ovary are drained by a common vein, the utero-ovarian vein, which is located caudally to the ovary. The ovarian artery connects to the ovary in close apposition to the utero-ovarian vein. In areas of apposition, the walls of the vessels are very thin as revealed histologically (Ginther, 1976). In its cranial regions, the uterine branch of the ovarian artery remains in tight apposition to the uterine branch of the utero-ovarian vein. The ovarian artery becomes extremely tortuous and convoluted, wrapping around the ovarian branch of the uteroovarian vein.

The tortuous network of utero-ovarian vessels in ruminants is in contrast to the simplistic utero-ovarian vasculature system of the mare. Although the uterus and the ovary share the same venous system, the ovarian artery does not come into contact with the uterine branch of the uteroovarian vein or the main portion of the ovarian vein in the mare (Del Campo et al., 1973). The mare's utero-ovarian artery is not tortuous, and is not in close apposition with the utero-ovarian veins. The arrangement of the main uterine vein and the main uterine arteries are similar in the ewe and the mare (Del Campo et al., 1973). In both species, the branches of the uterine veins remain close to the mesometrial attachment, while in the sow the venous branches form complex arches that extend the length of the uterine horn, intertwining with the highly branched uterine artery (Del Campo et al., 1973). The systemic utero-ovarian relationship of the mare is demonstrated by the inability of unilateral hysterectomy to maintain the CL on the ispilateral ovary, and the requirement of conceptus mobility during maternal recognition for luteal maintenance (Ginther, 1981; McDowell et al., 1988).

Because of extensive contact of veins and arteries, and the extensive size and length of the uterine horns, local uterine-ovarian relationships in the sow are demonstrated only when extensive 
surgical removal of uterine tissue is carried out. Complete removal of both uterine horns was required to prevent luteal regression in gilts (Anderson et al., 1961). Partial hysterectomies only slightly extended CL lifespan, even when only one-half of one uterine horn was left intact (Anderson et al., 1961). If a small portion of the opposite, non-gravid uterine horn in a unilaterally pregnant sow remains, both $\mathrm{CL}$ will regress, but the $\mathrm{CL}$ on the ipsilateral ovary will regress earlier than the CL on the opposite ovary (du Mesnil du Buisson, 1961 as cited by Anderson, 1977). In animals without a local relationship, as in the mare, the CL is regressed by very low dosages of $\mathrm{PGF}_{2 \alpha}$ (Douglas and Ginther, 1975a) in contrast to the large dosages required in the sow (Diehl and Day, 1974).

Countercurrent transfer has been the proposed mechanism by which uterine luteolysins or luteotropins are transported to the ovary in animals with local utero-ovarian relationships (Barrett et al., 1971; McCracken et al., 1971). Because of the close apposition of the utero-ovarian vasculature, substances have been thought to diffuse quickly from the utero-ovarian vein into the ovarian artery down the concentration gradient (Inskeep and Butcher, 1966; Barrett et al., 1971). Because $88 \%$ of $\mathrm{PGF}_{2 \alpha}$ is metabolized after one passage in the lungs, utero-ovarian transfer would concentrate uterine $\mathrm{PGF}_{2 \alpha}$ in the ovarian artery (Bonnin et al., 1999). Luteolysis failed to occur if the ovarian artery and utero-ovarian vein were separated in ewes (Inskeep and Butcher, 1966; 0Barrett et al., 1971). Likewise, Ginther et al. (1966) observed that treatment with oxytocin shortened the estrous cycle in unilaterally-hysterectomized heifers only if the uterine horn that was left intact was adjacent to ovary. Land et al. (1976) observed that concentrations of $\mathrm{PGF}_{2 \alpha}$ were higher in the ovarian artery than in the jugular vein or aorta on all days of the estrous cycle measured in non-stimulated ewes (Land et al., 1976). However, in studies using 
tritiated $\mathrm{PGF}_{2 \alpha}$, only $0.5 \%$ (Land et al., 1976) to $2 \%$ (McCracken et al., 1972) of $\mathrm{PGF}_{2 \alpha}$ was detected to actually transfer from the utero-ovarian vein to the ovarian artery. Milvae and Hansel (1980) were unable to detect an increase in $\mathrm{PGF}_{2 \alpha}$ in ovarian arterial plasma in oxytocin-treated heifers despite showing increases in $\mathrm{PGF}_{2 \alpha}$ in uterine venous plasma.

Bonnin et al. (1999) investigated the means by which the ovarian artery contains higher concentrations of $\mathrm{PGF}_{2 \alpha}$ without a significant contribution from countercurrent transfer. The halflife of $\mathrm{PGF}_{2 \alpha}$ was 26 minutes in the femoral artery, but was 108 minutes in the distal ovarian artery. Increased half-life may be due to diffusion of $\mathrm{PGF}_{2 \alpha}$ out of the ovarian vein and into the distal ovarian artery through the vessel walls and through uterine lymphatics in the broad ligament. Uterine lymphatics may act as a sink for $\mathrm{PGF}_{2 \alpha}$ and release $\mathrm{PGF}_{2 \alpha}$ into the uteroovarian vein and the ovarian artery. This finding is in agreement with Heap et al. (1985). After an injection of tritiated $\mathrm{PGF}_{2 \alpha}$ into the uterine lumen, the utero-ovarian vein contained the highest concentration of $\mathrm{PGF}_{2 \alpha}$ for the first 30 minutes, then the concentration of $\mathrm{PGF}_{2 \alpha}$ was the highest in the uterine lymph vessels for as long as 120 minutes (Heap et al., 1985). Bonnin et al. (1999) measured concentrations of $\mathrm{PGF}_{2 \alpha}$ in the uterine vein, the distal ovarian artery, and the femoral artery after an oxytocin challenge in ewes. There was a 30-minute delay between maximal concentrations of $\mathrm{PGF}_{2 \alpha}$ in the uterine vein after oxytocin challenge and maximal concentration of $\mathrm{PGF}_{2 \alpha}$ in the ovarian artery. It was observed that $33 \%$ of $\mathrm{PGF}_{2 \alpha}$ reached the ovary by rapid systemic transfer, which was then followed by a delayed local transfer of $67 \%$ of the $\mathrm{PGF}_{2 \alpha}$ lasting several hours (Bonnin et al., 1999). The authors concluded that the $\mathrm{PGF}_{2 \alpha}$ that reached the ovary was from three sources. Approximately one-third was from systemic circulation, one-third was by diffusion from the utero-ovarian vein, and one-third was by diffusion from the uterine lymphatics. 
The utero-ovarian relationship is comprised of: 1) the effect of the ovary on the uterus, 2) the effect of the ovary on the ovary, 3) the effect of the uterus on the ovary, and 4) the effect of one uterine horn upon the other. The degree of the local relationship exhibited in these associations is dependent upon the species, and the stage of estrous cycle or pregnancy status of the animal.

\section{The effect of the ovary on the uterus}

Embryos transferred into cows with estrous cycles of normal length had a greater rate of survival when placed into the portion of the uterus closest to the ovary with the CL (Newcomb et al, 1980). When the embryo was placed into the uterine horn contralateral to the ovary with the CL, survival rate of embryos did not differ whether the embryo was placed in the tip of the horn or at the base of the horn (Newcomb et al., 1980).

One cause of the disparity of embryonic rates of survival with regard to location may be explained by the distribution of progesterone in the uterine tissue. Weems et al. (1989) found that concentrations of progesterone in uterine tissue were highest in the cranial third of the horn adjacent to the ovary bearing the CL in ewes on day 4 of the estrous cycle. On day 10 , the cranial portion of the horn ipsilateral to the ovary bearing the CL contained more than double the concentration of progesterone when compared to the caudal third of the ipsilateral horn and all regions of the contralateral horn. Regardless of day of sampling, concentrations of progesterone in the blood from the cranial uterine vein of the ipsilateral uterine horn were two-fold higher than concentrations in jugular blood. Although progesterone has a systemic effect, higher local 
concentrations give an advantage to the embryo placed nearest to the CL. This systemicallycirculating steroid can have local implications due to the vascular associations between the ovary and the uterus, which increase local steroid concentrations.

An extreme example of the local effect of CL on the uterus is found in the giant fruit bat. Although both ovaries and both uterine horns are functional, after an ovulation, the extreme distal portion of the ipsilateral uterine horn develops glands typical of a pregnant uterus ( and this is where implantation occurs) while the glands in the other portions of the uterus remain in an estrous state (Marshall, 1953). Neither direct nervous nor vascular connections were found, but there was an isthmus connecting the ovary to the uterine horn (Marshall, 1953). Sheer proximity of the CL to the uterus may be responsible for this localized nidation.

\section{The effect of the ovary on the ovary}

The products of an ovary can have immediate effects by both intraovarian and extraovarian local pathways. The CL appears to have a very localized influence on the ovary in which it was produced. The number of follicles, the rate of follicular growth, and follicular fluid weight were greater on the ovary containing the CL in cows, sows, and ewes (Dufour et al, 1971; Clark et al., 1975; Rexroad and Casida, 1975). Because this effect is not limited to monovulatory species, which consistently ovulate from one ovary, intraovarian or extraovarian transfer of ovarian products affects the ovary secreting those products. Injection of $\mathrm{PGF}_{2 \alpha}$ into a follicle caused regression of the CL on the same ovary (Fogwell et al., 1977). The effect was not prevented by a latex barrier in bisected ovaries when the CL was located on the opposite portion of the ovary from the follicle injected with $\mathrm{PGF}_{2 \alpha}$, indicating the presence of local extraovarian 
pathways, because the latex barrier was not penetrated by $\mathrm{PGF}_{2 \alpha}$ in vitro.

\section{The effect of the uterus on the ovary}

The embryo must prevent luteal regression for establishment of pregnancy. The exact mechanism of maternal recognition of pregnancy depends on the species, and may include strategies for either reducing secretion or action of uterine luteolysins or promoting the secretion of luteotropins. A local relationship is obvious in species such as the Canadian porcupine in which accessory CL on the ovary contralateral to the gravid uterine horn regress (Mossman and Judas, 1949). In the ewe, however, embryos can exist in the uterine horn opposite to the CL (Niswender and Dziuk, 1966). Embryos were found to migrate to the uterine horn opposite to the ovary that ovulated in $2 \%$ of the ewes with a single ovulation and $50 \%$ of the ewes with two ovulations on the same ovary (Boyd et al., 1944).

Although the ewe may first appear to use a systemic pathway during maternal recognition, Moor and Rowson (1966) were able to demonstrate a local pathway. They transferred two day-5 embryos into unilaterally-ovulating ewes and ligated, then severed, one uterine horn just cranial to the internal bifurcation. If the embryos were in the isolated horn when it was ipsilateral to the ovary bearing the CL, 8 of the 10 recipients maintained the CL and pregnancy. However, if the isolated gravid horn was contralateral to the ovary bearing the CL, 0 of the 15 recipients maintained the CL and pregnancy. Therefore, a local luteotropic or antiluteolytic effect of the embryo may not be distinguishable because of the confluence of the uterine horns.

When investigating the role of uterine distention as a signal for maternal recognition, Moore and Nalbandov (1953) found that paraffin beads placed in ewes on day 3 of the estrous 
cycle actually shortened rather than extended luteal lifespan. They hypothesized that the uterus directly communicated with the pituitary, inducing a reduction of gonadotropins necessary for luteal support. Ewes in which the portion of the uterine horn containing the bead was surgically isolated had estrous cycles of normal length (Moore and Nalbandov, 1953). They concluded that the separation of the uterine horn acted to "denervate" it, and thus uncouple the proposed nervous connection of the uterus from the pituitary. Consequently, this effect was studied for decades, and the luteolytic mechanism of the uterus was elucidated.

Species that do not have uterine caruncles, such as the rat, pig, woman, and monkey, do not respond to an intrauterine device (IUD) by a shortened luteal phase (Hawk, 1968). An IUD inserted on day 2 in one or both uterine horns caused a higher concentration of $\mathrm{PGF}_{2 \alpha}$ in uterine venous plasma, and higher $\mathrm{PGF}_{2 \alpha}$ in uterine tissue in the ewe (Pexton et al., 1975). In bilaterallyovulating ewes with one IUD, the horn bearing the IUD contained higher caruncular concentrations of $\mathrm{PGF}_{2 \alpha}$ (Pexton et al., 1975). Consequently, the CL on the ovary ipsilateral to the IUD weighed less than the CL on the contralateral ovary, but the CL on the contralateral side was not as heavy as the CL in ewes with no IUD (Pexton et al., 1975). This is another example of a local relationship with systemic components.

The effect that one uterine horn can have on the other and the role of the vasculature in the region between the internal and external bifurcations of the uterine horns can be examined by separating or ligating the uterine horn containing the IUD. If an IUD was inserted on day 1 into the uterine horn contralateral to the ovary bearing the CL, the CL regressed, but if the uterine horn ipsilateral to the CL was removed, the CL was maintained (Ginther, 1970). If an IUD was placed in ewes on day 1 after the onset of estrus contralaterally to the ovary with the CL, and the 
horn was ligated and severed caudad to the IUD, despite ligation, the CL on the contralateral ovary still regressed (Ginther, 1970). However, an IUD placed in the uterine horn opposite to the ovary with the CL on day 4, even without surgical interference, failed to influence the CL (Ginther, 1966). This study demonstrated an effect of the transient increase in the number of vascular connections that were present during and shortly after estrus (Dobrowlski and Hafez, 1970). The influence that one horn may have on the other declines as the cycle continues. Without surgical interference, IUD insertion at day 1 appeared to have a systemic effect (Ginther, 1970), at day 2 the effect appeared to be somewhat local (Pexton, 1975), and at day 4 the effect of IUD on the CL was localized (Ginther et al., 1966).

Partial hysterectomies have been a useful tool for studying the local relationships related to secretion of $\mathrm{PGF}_{2 \alpha}$. When the uterine horn ipsilateral to the $\mathrm{CL}$ was removed in ewes, the luteal phase could be extended for over 36 days (Inskeep and Butcher, 1966). However, a normal length luteal phase ensued after a unilateral hysterectomy on the side opposite to the ovary bearing the CL (Inskeep and Butcher, 1966).

During the estrous cycle, the ability of the uterus to control the ovary is mainly by the secretion of $\mathrm{PGF}_{2 \alpha}$. In fact, it appears that the CL may be under constant inhibition by the uterine secretion of $\mathrm{PGF}_{2 \alpha}$. Removal of caruncular tissue in ewes resulted in a two- to three-fold increase in peripheral concentrations of progesterone during the luteal phase of estrous cycles that were observed for 6 months (Robinson et al., 1976).

As pregnancy progresses, the role of the uterus changes. In the ewe, a CL from a 90-day pregnancy was responsive (increase in secretion of progesterone) to $\mathrm{PGE}_{2}$, but not $\mathrm{LH}$ (Weems et al., 1997). The exact time of this alteration in dependence is not known. On days 15 to 18 of 
pregnancy in the cow, the main source of estradiol- $17 \beta$ is from the uterus rather from the ovary (Schallenberger et al., 1989). Between days 31 to 33 there is a 10-fold increase in secretion of $\mathrm{PGF}_{2 \alpha}$ and $\mathrm{PGI}_{2}$ from the pregnant cow uterus, and this period is associated with higher rates of embryonic mortality (Schallenberger et al., 1989). The CL of pregnancy can be replaced by a new CL induced by treatment with hCG during progesterone replacement therapy (Lulai et al., 1994; Wright et al., 1994; Bridges et al., 2000). The induced CL must be located on the ovary ipsilateral to the gravid horn, indicating the presence of local relationships at this stage of pregnancy in the cow (Wright et al., 1994). Induction of CL prior to day 36 resulted in maintenance of $50 \%$ of the pregnancies whereas induction of CL after day 36 resulted in the maintenance of pregnancy in $100 \%$ of the cows (Wright et al., 1994; Bridges et al., 2000). Cows tended to maintain more pregnancies after induction of CL prior to day 36 if they had higher concentrations of $\mathrm{PGF}_{2 \alpha}$ and lower concentrations of estradiol-17 $\beta$ during days 31 to 35 of pregnancy. Concentrations of progesterone were higher in cows with higher concentrations of $\mathrm{PGF}_{2 \alpha}$ during days 31 to 35 . At this stage of pregnancy, $\mathrm{PGF}_{2 \alpha}$ may be beneficial, as it has been demonstrated to facilitate attachment of the embryo in the rat (Kennedy, 1977).

\section{Uterine contractility}

Once an embryotoxic factor(s) of ovarian origin reaches the uterus, whether the factor affects embryos in only one, or both uterine horns may depend upon the ability of the factor(s) to move through the lumen of the uterine horns. The uterus is a dynamic organ that is undergoing contractions constantly. Therefore, distribution of the factor(s) may depend not only upon 
previously discussed vascular connections between the uterine horns, but also on the pattern of contractility.

The patterns and frequency of uterine contractility differ under the influence of the dominant steroid, but the uterus is active at all stages of the estrous cycle. In the ewe, during estrus or after exogenous estrogen treatment, the uterus was pink and turgid and had rapid, powerful contractions (Hawk, 1975). The number of uterine contractions was high, and the majority of contractions originated in the most anterior portion of the uterine body and was directed toward the oviducts (Croker and Shelton, 1973; Hawk, 1975). During the end of estrus, the uterus was darker in color with longer and slower moving contractions. The frequency of contractions declined and the direction of contractions were toward the cervix. Some contractions originated in the middle of the uterine horn with no definite direction. These contractions were powerful and did not vary with the stage of the estrous cycle.

In some species, the coordination of contractile activity of the uterus has been demonstrated by the ability of the uterus to transport inert particles. The uterus quickly transported radio-opaque substances to the oviducts after artificial insemination in cows (Rowson, 1955). Evidence of uterine transport exists in gilts. Viring et al. (1980) mixed radio-labeled substances with seminal plasma and surgically introduced this mixture into the uterine horn of gilts 24 hours after the onset of estrus. As quickly as 5 minutes later, each type of radio-labeled compound had traveled to the opposite horn, and even into the opposing oviduct. The movement of rubber pellets in the uterus in bred ewes was greatest when the pellets were placed into the uterine horn ipsilateral to the ovulating ovary (Cloud and Casida, 1969). 
Although luteal regression occurs during a time when the uterus is more quiescent than during estrus, uterine concentrations of $\mathrm{PGF}_{2 \alpha}$ are elevated during early luteal regression. The addition of prostaglandins to ram semen increased uterine contractility patterns and increased fertility (Dimov and Georgiev, 1977). Uterine transport is thought to be crucial to successful fertilization. However, cessation of coordinated uterine contractions induced with 400 USP units of oxytocin did not affect the number of sperm reaching the oviducts (Sayre, 1995). Therefore, substances in the uterine lumen appear to be able to disperse throughout the uterine horns, even when contractility is inhibited.

\section{The embryotoxic factor}

$\mathrm{PGF}_{2 \alpha}$ is the most obvious candidate for the embryotoxic factor of luteal origin referred to in the introduction. However, several inconsistencies exist in the data that leave the identity of the embryotoxic factor in question.

Relative to the stage of embryonic development, in vitro incubation of embryos with $\mathrm{PGF}_{2}$ $\alpha$ was detrimental to embryonic maturation. Development of 8-cell rat embryos into morulas was inhibited by incubation with $\mathrm{PGF}_{2 \alpha}$ (Breuel et al., 1993). Rabbit embryos at the 2-, 4-, or 8-cell stage, incubated with $\mathrm{PGF}_{2 \alpha}$, were inhibited in their ability to hatch and elongate, but no effect was observed when rabbit blastocysts were incubated with $\mathrm{PGF}_{2 \alpha}$ (Maurer and Beier, 1976). The importance of timing was emphasized further by the fact that chronic treatment of $\mathrm{PGF}_{2 \alpha}$ caused embryonic mortality in cows when administered on days 4 through 7 or 5 through 8 after mating (Buford et al., 1996; Seals et al., 1998), but not on days 10 through 13 or 15 through 18 (Seals et al., 1998). 
Postpartum cows expected to have a short luteal phase had higher concentrations of $\mathrm{PGF}_{2}$ ${ }_{\alpha}$ in uterine flushings than postpartum cows expected to have normal CL (Schrick et al., 1993). Cows with lower concentrations of $\mathrm{PGF}_{2 \alpha}$ tended to have higher quality embryos on day 6 on a within treatment basis, but no significant difference in embryo quality or stage of development was observed in cows expected to have short-lived versus normal CL (Schrick et al., 1993). The combination of relatively fewer ova recovered as embryos and relatively lower survival of embryos transferred into cows with normal length cycles led to a lower pregnancy rate when embryos were from cows with a short-lived CL than from cows with a CL with normal life span. Future maturation of an embryo from an animal with a shortened luteal phase was compromised even when transferred on day 6 into a cow with a normal length luteal phase (Schrick et al., 1993).

Although there are numerous variations in the CL and endometrium of postpartum cows expected to have a short luteal phase, mimicking one variable by chronic administration of $\mathrm{PGF}_{2 \alpha}$ to cycling cows supplemented with progestogens induced a reduction in embryonic survival similar to that seen in the postpartum cow. Treatments that improved embryonic survival in postpartum cows with short-lived CL and cycling cows treated with exogenous $\mathrm{PGF}_{2 \alpha}$ were somewhat different. In cows treated with $\mathrm{PGF}_{2 \alpha}$, lutectomy alone returned embryonic survival to normal values (Buford et al., 1996). In postpartum cows expected to have a short-lived CL, neither flunixin meglumine nor lutectomy alone was able to increase pregnancy rates, but the combination of the two increased pregnancy rates (Buford et al., 1996).

Oxytocin was implicated as a possible embryotoxic factor because it was released from the CL after treatment with $\mathrm{PGF}_{2 \alpha}$ (Buford et al., 1996; Lemaster et al., 1999). In cows given 
exogenous progesterone, administration of oxytocin every 8 hours on days 5 through 8 , induced luteal regression and lowered pregnancy rates (Lemaster et al., 1999). Treatment with flunixin meglumine, but not lutectomy, was able to restore pregnancy rates in such oxytocin-treated cows (Lemaster et al., 1999). The authors proposed that oxytocin was indirectly embryotoxic by stimulating uterine secretion of $\mathrm{PGF}_{2 \alpha}$. Indeed, the greatest elevation of concentrations of oxytocin $(50 \mathrm{pg} / \mathrm{mL})$ in jugular plasma occurred in cows treated with $\mathrm{PGF}_{2 \alpha}$ on either day 5 or 10 through 13 or 15 through 18, in which a decline in pregnancy rate was not observed (Seals et al., 1999).

A positive feedback loop between oxytocin and uterine $\mathrm{PGF}_{2 \alpha}$ was proposed as another possibility, with $\mathrm{PGF}_{2 \alpha}$ becoming the ultimate embryotoxin. This is consistent with the work of Milvae and Hansel (1980) in which heifers received exogenous oxytocin early in the estrous cycle (days 2 through 6 or days 5 through 6). Heifers treated with oxytocin had increased concentrations of $\mathrm{PGF}_{2 \alpha}$ in uterine venous blood similar to concentrations observed during luteal regression. Increased concentrations of $\mathrm{PGF}_{2 \alpha}$ were not detected in ovarian arterial blood. The interval to estrus depended on the frequency of oxytocin treatment, but all oxytocin-treated heifers had lower progesterone concentrations indicative of reduced luteal function. When Lemaster et al. (1999) removed the CL in oxytocin-treated cows, pregnancy rates were not restored, apparently because the 'positive feedback loop' was still functional due to exogenous oxytocin (Lemaster et al., 1999). Therefore, the ability of flunixin meglumine to restore pregnancy rate most likely involved inhibition of secretion of uterine $\mathrm{PGF}_{2 \alpha}$.

The type of utero-ovarian relationship by which the CL decreases embryonic survival was investigated by Hernandez-Fonseca et al. (2000). Day-6 embryos were transferred into the 
uterine horns ispilateral and contralateral to the CL that was induced to regress in progestogensupplemented cows. Treatment with $\mathrm{PGF}_{2 \alpha}$ every eight hours on days 5 through 8 decreased pregnancy rates (33\% in treated vs. $67 \%$ in control), but the location of the embryo in relation to the CL did not affect survival. It appeared that the effect of the regressing CL on embryonic survival was systemic; embryos placed into the uterine horn ipsilateral or contralateral to the regressing CL had the exactly the same rate of survival (33\%; Hernandez-Fonseca et al., 2000). However, this experiment did not rule out transfer of an embryotoxin through the uterine lumen after local effects of the regressing CL on the adjacent uterine horn. 


\section{STATEMENT OF THE PROBLEM}

Insemination of cows at the first postpartum estrus or estrus induced by early weaning rarely results in a pregnancy. Pregnancy rates are lower when ewes are bred out-of-season. However, the ability of an early-weaned postpartum beef cow to ovulate an ovum capable of fertilization, development to the 4-cell stage, and transport into the uterus was not impaired (Breuel et al., 1993).

The first luteal phase after parturition in cows or after the seasonal anestrus in ewes is usually abbreviated. Although the short-lived CL is an obvious cause of low pregnancy rates, supplementation with progesterone after the first ovulation did not increase pregnancy rates. However, the combination of removal of the CL and administration of an inhibitor of prostaglandin synthesis improved pregnancy rates in early postpartum cows. In cows and ewes with normal estrous cycles, CL regression reduced pregnancy rates, despite supplementation with progesterone. Removal of the CL increased embryonic survival in animals induced to have a short-lived CL. Therefore, the presence of a short-lived CL is toxic to embryos.

Luteolysis in ruminants is a local physiologic event that involves the ovary bearing the CL and the nonpregnant uterine horn ipsilateral to that ovary. This local physiological relationship is possible because the venous and lymphatic drainage of the uterus is in close proximity to the artery supplying the ovary. Blood and lymph vessels of the uterus transfer $\mathrm{PGF}_{2 \alpha}$ directly to the ovarian artery by slow diffusion. The $\mathrm{PGF}_{2 \alpha}$ that is not metabolized by the lungs, approximately $12 \%$, reaches the ovary through systemic circulation. Luteolysis in ruminants involves secretion 
of $\mathrm{PGF}_{2 \alpha}$ and oxytocin from the $\mathrm{CL}$; the later hormone has been shown to stimulate secretion of $\mathrm{PGF}_{2 \alpha}$ from the uterus, at least in pharmacological situations.

Hernandez-Fonseca et al. (2000) transferred embryos into the uterine horn that was either ipsilateral or contralateral to the ovary bearing the regressing CL in order to determine if the regressing CL killed embryos by a systemic or local route. Embryonic survival did not differ whether the embryo was in the uterine horn adjacent to the ovary bearing the regressing CL or in the uterine horn opposite to the ovary with the regressing CL. However, local relationships are difficult to distinguish because exchange of substances can occur between the two uterine horns through the uterine lumen. In ruminants, the events of maternal recognition and luteal regression are local phenomena, but this was not elaborated until the uterine horns were severed or ligated. The regressing corpus luteum may be a source of prostaglandins, oxytocin, or other factors that, once in the uterine lumen, are detrimental to embryonic development. The uterine myometrium has sufficient contractile activity during the luteal phase to move substances from one uterine horn into the other. The objectives of these experiments were to determine if there is an embryotoxic effect of a short-lived CL in the ewe and if that effect is systemic or local. Elucidation of this relationship will add to our understanding of the mechanism of the embryotoxicity of a short-lived CL. 


\section{MATERIALS AND METHODS}

\section{Experiment 1) Effects of $\mathrm{PGF}_{2 \alpha}$ alone or in combination with lutectomy on pregnancy rate}

in ewes.

Estrus was synchronized in ewes of mixed breeding (mainly Suffolk and Dorset) by two injections of $5 \mathrm{mg}$ Lutalyse ${ }^{\circledR}$ (Pharmacia \& Upjohn, Kalamazoo, MI) at a 4-hour interval. At estrus, ewes were mated by at least two fertile rams. Ewes received an intravaginal pessary containing $60 \mathrm{mg}$ flurogestone acetate from day 4 after estrus until pregnancy diagnosis. On the

afternoon of day 4 , ewes were anesthetized with 25 to $35 \mathrm{mg} / \mathrm{kg}$ of sodium pentobarbital, and a midventral laparotomy was performed to expose the reproductive tract. Ewes were assigned randomly to receive either a sham surgery or complete lutectomy (figure 1). Number and location of ovulation was not of concern in this experiment, and, consequently, all CL were removed or all CL were left intact.

Following surgery, ewes were assigned randomly to receive either saline or $5 \mathrm{mg} \mathrm{PGF}_{2 \alpha}$ every 8 hours for either two or three days. On day 25, pregnancy was determined on a per ewe basis by transrectal ultrasonography using an Aloka 500 ultrasound console fitted with a $7.5 \mathrm{MHz}$ transducer. Differences among treatments were determined by Chi-Square, with the CATMOD procedure of SAS (1995). 
Figure 1. Design of experiment 1. Arrows indicate removal of corpora lutea.

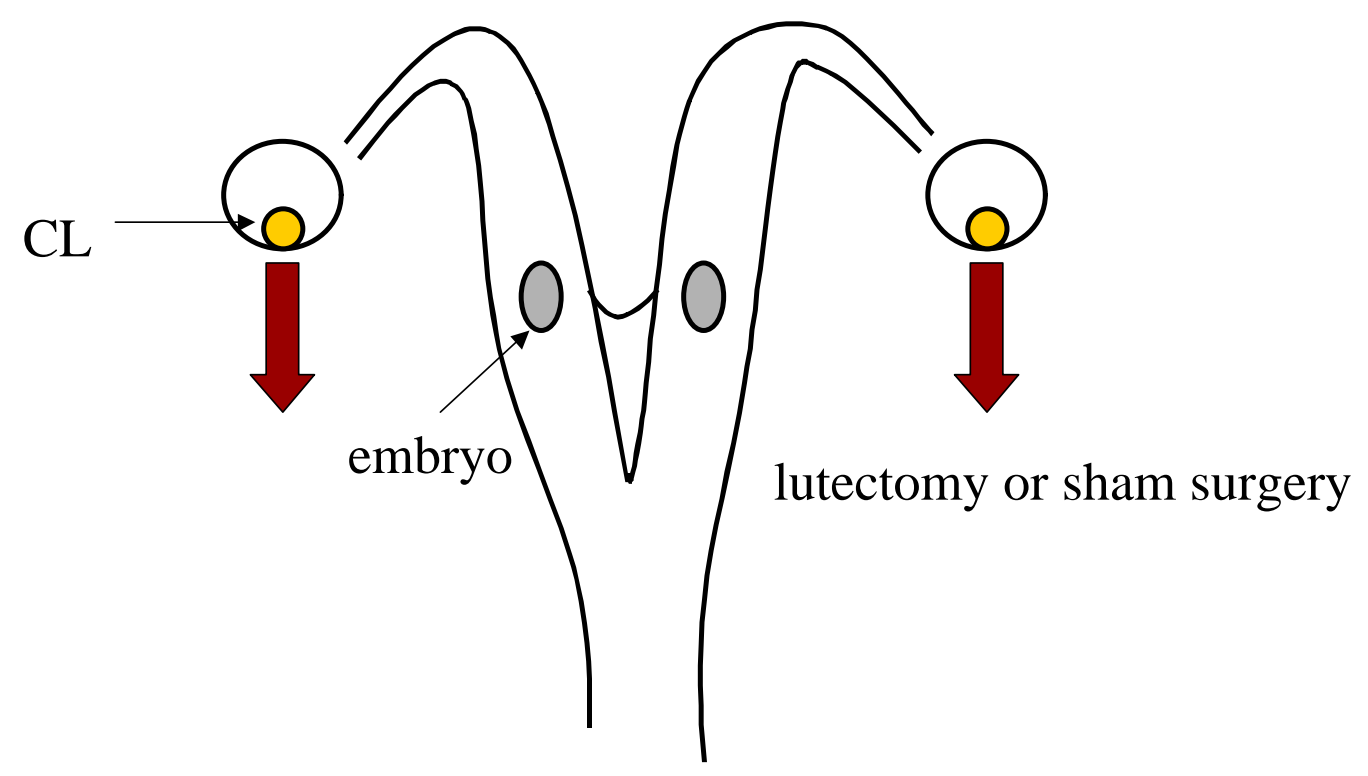




\section{Experiment 2) Effects of $\mathrm{PGF}_{2 \alpha}$ or saline plus unilateral lutectomy on embryonic survival in the isolated uterine horn ipsilateral or contralateral to the $C L$ in ewes.}

Ewes of mixed breeding were checked daily for estrus with a vasectomized ram. Between 5 and 10 days after estrus, each ewe was treated with two intramuscular injections of $\mathrm{PGF}_{2 \alpha}(5$ mg), 4 hours apart, to synchronize estrus. Ewes were observed for estrus every 12 hours, and those exhibiting estrus were mated by two different fertile rams. Ovaries were observed by transrectal ultrasonography on the morning of day 4 post-mating to detect corpora lutea. Ewes with at least one corpus luteum on each ovary were selected for use in the experiment. To provide hormonal support of pregnancy after regression of corpora lutea in treated ewes, each ewe received a subcutaneous injection of $25 \mathrm{mg}$ progesterone every 12 hours beginning on the morning of day 4 and continuing until day 25. On the afternoon of day 4 , ewes were anesthetized with 25 to $35 \mathrm{mg} / \mathrm{kg}$ of sodium pentobarbital, and a midventral laparotomy was performed to expose the reproductive tract. One ovary was selected at random, and the CL was removed by digital pressure.

Each uterine horn was ligated cranial to the internal bifurcation and caudal to the external bifurcation, isolating the uterine horns from the uterine body (figure 2). Suture was passed underneath the perimetrium, and around the myometrium of the horn, thereby avoiding the mesenteric ligaments and major vasculature. The ligature was anchored by stitches through the perimetrium on the dorsal side of the uterus. The ability of the ligatures to prevent the flow of uterine contents was tested in two ewes in a preliminary trial. After ligation one uterine horn was injected with $5 \mathrm{~mL}$ India Ink, and the tract was examined one week after surgery. The ink did not pass the ligatures in either ewe. 
Figure 2. Design of experiment 2.

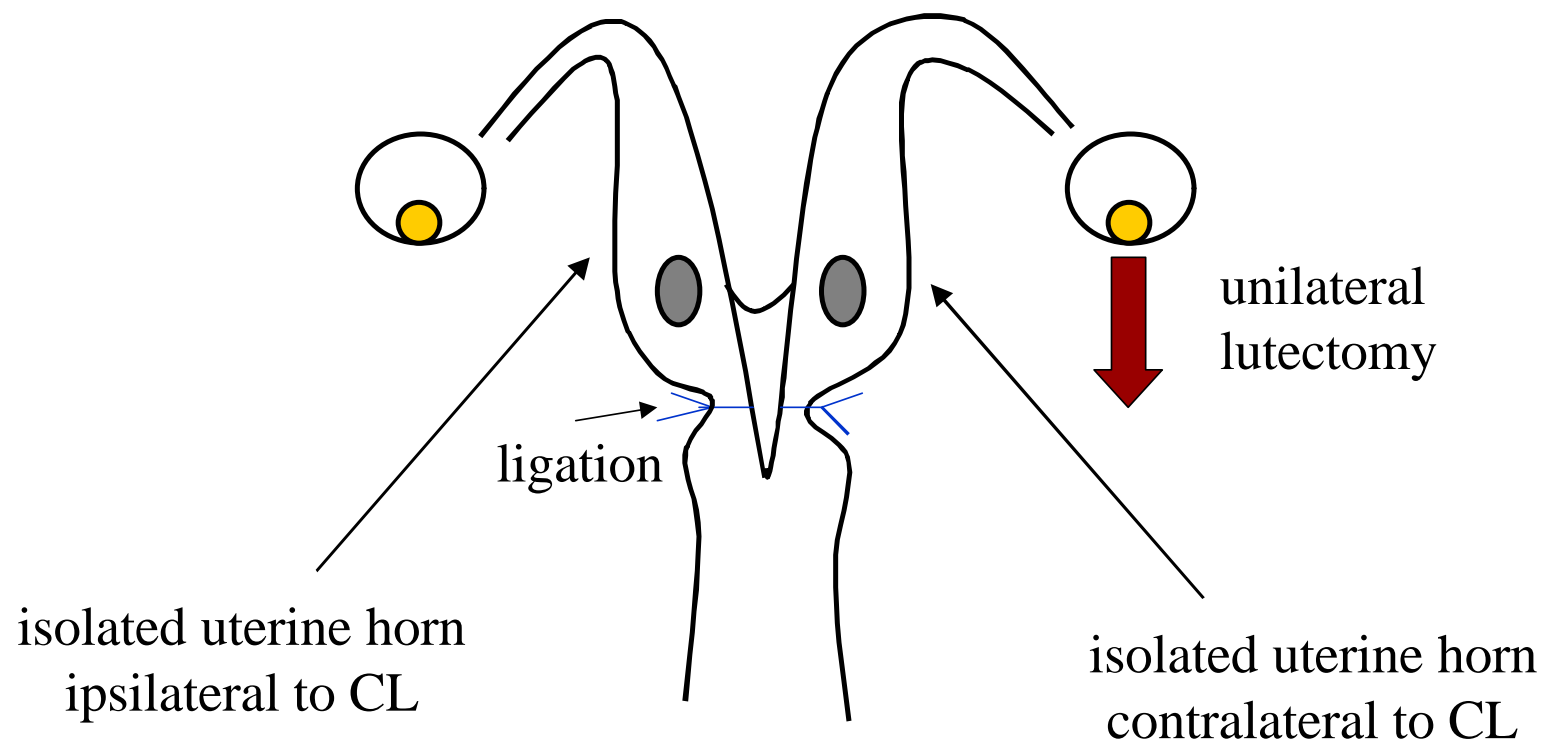


Beginning on the morning of day 5 , ewes were assigned at random to receive either $5 \mathrm{mg}$ $\mathrm{PGF}_{2 \alpha}(\mathrm{n}=19)$ or saline $(\mathrm{n}=15)$ every 8 hours for three days. Each uterine horn was examined for pregnancy and the presence of a fetal heartbeat by transrectal ultrasonography on day 25 .

The effect of treatment, location of the embryo in respect to the regressing CL, and treatment by location interaction on pregnancy was tested by Chi-Square, with the CATMOD procedure of SAS (1995). In order to determine, in ewes that were pregnant, if treatment with $\mathrm{PGF}_{2 \alpha}$ reduced the number of embryos per ewe, a chi square analysis of a 2 x 2 contingency table was used. To avoid bias, only ewes with exactly two ovulations were used to test if treatment affected the number of embryos per ewe in pregnant ewes.

In four of the ewes that were treated with $\mathrm{PGF}_{2 \alpha}$, membranes and fluid were observed in the uterus during ultrasonography on $\mathrm{d} 25$. When the reproductive tracts from these ewes were examined after slaughter and no embryos were present. 


\section{RESULTS}

\section{Experiment 1:}

Treatment of progestogen-supplemented ewes with $\mathrm{PGF}_{2 \alpha}$ resulted in a lower percentage of ewes that were pregnant, 33\% (5 of 15 ewes), compared to saline-treated ewes, which had a pregnancy rate of $86 \%$ (12 of 14 ewes; $\mathrm{P}<0.001$ ). Removal of corpora lutea in $\mathrm{PGF}_{2 \alpha}$-treated ewes resulted in an intermediate pregnancy rate $(\mathrm{P}<0.05$; table 1$)$. The percentage of ewes pregnant after treatment for 2 or 3 days did not differ $(\mathrm{P}>0.05$; table 1$)$.

Table 1. Pregnancy rates of ewes treated with $\mathrm{PGF}_{2 \alpha}$ or saline receiving complete lutectomy or sham surgery (Experiment 1 ).

\begin{tabular}{lccc}
\hline & \multicolumn{3}{c}{ Pregnancy Rate (\%) } \\
\cline { 2 - 4 } Treatment & Injections for 2d & Injections for 3 d & Overall \\
\hline Saline + Sham & $7 / 8$ & $5 / 6$ & $12 / 14^{\mathrm{a}}$ \\
& $(88)$ & $(83)$ & $(86)$ \\
$\mathrm{PGF}_{2 \alpha}+$ Sham & $4 / 8$ & $1 / 7$ & $5 / 15^{\mathrm{b}}$ \\
& $(50)$ & $(14)$ & $(33)$ \\
$\mathrm{PGF}_{2 \alpha}+$ Lutectomy & $5 / 7$ & $5 / 10$ & $10 / 17^{\mathrm{c}}$ \\
& $(71)$ & $(50)$ & $(59)$ \\
\hline
\end{tabular}

${ }^{\mathrm{abc}}$ Values within a column with different superscripts differed $(\mathrm{P}<0.05)$. 


\section{Experiment 2:}

Treatment of progestogen-supplemented ewes with $\mathrm{PGF}_{2 \alpha}$ reduced the percentage of ewes pregnant to $53 \%$ (10 of 19 ewes) compared to saline-treated ewes, of which 87\% (13 of 15 ewes; $\mathrm{P}<0.01$ ) were pregnant. On a per horn basis, $77 \%$ of uterine horns were pregnant in salinetreated ewes, but treatment with $\mathrm{PGF}_{2 \alpha}$ reduced the percentage of uterine horns pregnant to $34 \%$ ( $\mathrm{P}<0.01$; table 2 ). However, the ability of the embryo to survive was not altered by the location of the embryo with respect to the CL (treatment $\mathrm{x}$ horn, $\mathrm{P}>0.10$ ). In $\mathrm{PGF}_{2 \alpha}$-treated ewes, 5 of 19 embryos survived in the uterine horn ipsilateral and 8 of 19 survived in the uterine horn contralateral to the regressing CL (table 2). There was no effect of replicate.

Table 2. Pregnancy rates by uterine horns in ewes treated with saline or $\mathrm{PGF}_{2 \alpha}$ (Experiment 2).

\begin{tabular}{llll}
\hline & \multicolumn{3}{c}{ Pregnancy Rate (\%) } \\
\cline { 2 - 4 } Treatment & Ipsilateral & Contralateral & Overall \\
\hline Saline & $13 / 15$ & $10 / 15$ & $23 / 30^{\mathrm{a}}$ \\
& $(87)$ & $(67)$ & $(77)$ \\
$\mathrm{PGF}_{2 \alpha}$ & $5 / 19$ & $8 / 19$ & $13 / 38^{\mathrm{b}}$ \\
& $(26)$ & $(42)$ & $(34)$ \\
\hline
\end{tabular}

${ }^{\mathrm{ab}}$ Values within a column with different superscripts differed $(\mathrm{P}<0.05)$.

Treatment with $\mathrm{PGF}_{2 \alpha}$ in progesterone-supplemented ewes reduced the percentage of ewes pregnant. However, treatment with $\mathrm{PGF}_{2 \alpha}$ may also reduce the number of embryos per ewe in progesterone-supplemented ewes that maintained pregnancy. To be sure that ovulation rate did 
not cause bias in the results, only ewes with exactly two ovulations were included in the analysis. Only 2 of the 9 pregnant ewes that were treated with $\mathrm{PGF}_{2 \alpha}$ had two embryos, whereas 7 of 10 pregnant saline-treated ewes had two embryos (table 3). This effect was not significant possibly due to the low number of ewes used in this analysis $(\mathrm{P}<0.25)$.

Table 3. Frequency of ewes with one or two embryos after treatment with saline or PGF $_{2 \alpha}$ in ewes that ovulated once on each ovary and had one CL removed (Experiment 2).

\begin{tabular}{lccc} 
& \multicolumn{3}{c}{ Number of embryos/ ewe } \\
\cline { 2 - 4 } Treatment & 1 & 2 & Total \\
\hline Saline & 3 & 7 & 10 \\
PGF $_{2 \alpha}$ & 7 & 2 & 9 \\
\hline Total & 10 & 9 & 19 \\
\hline
\end{tabular}

Chi-Square $\chi^{2}=2.63$ effect of treatment on number of embryos in pregnant ewes $(\mathrm{P}<0.25)$.

\section{DISCUSSION}

The regressing CL had an embryotoxic effect in the ewe as had been reported previously in the cow (Buford et al., 1996; Seals et al., 1999). The fact that the reduction in embryonic survival did not differ if the embryo was located in the uterine horn ipsilateral or contralateral to the regressing CL is consistent with the findings of Hernandez-Fonseca et al. (2000) in cows. When Hernandez-Fonseca et al. transferred day-6 embryos into progestogen-supplemented cows with induced early luteal regression, the survival rate was $33 \%$ regardless of whether an embryo was transferred to the uterine horn ipsilateral or contralateral to the ovary bearing the regressing CL, compared to $67 \%$ in control cows. The prevention of the flow of luminal uterine contents between horns did not affect embryonic survival in the uterine horn contralateral to the ovary 
bearing the regressing $\mathrm{CL}$ in ewes in experiment 2. Therefore, the embryotoxic effect of a shortlived CL is systemic in both the cow and the ewe.

The lack of a local effect of the embryotoxic factor from the short-lived CL reduces the likelihood that some of the components of the inflammatory reaction of CL regression act as embryotoxins as suggested by Buford et al. (1996). Macrophages and the cytokine they secrete, interleukin-1 (IL-1) have been implicated in luteal regression (Pate, 1995); IL-1 activates T-cells. Both T-cells and macrophages produce tumor-necrosis factor (TNF), which has anti-tumor activity and has been shown to stimulate secretion of $\mathrm{PGF}_{2 \alpha}$ by bovine luteal cells in combination with IL-1 (Pate, 1995). However, cell-mediated immunity during luteal regression is a specific event. In addition, a wide variety of antigens are expressed on the embryo from the earliest stages of growth (Palm et al., 1971), and the major histocompatibility complex antigens have been shown to be expressed on mouse embryos as early as day 6 (Searle et al., 1976). The early embryo is antigenic but not immunogenic. Immunogenecity may be prevented by coating the embryo with uterine proteins or by active suppression of the immune cells. Extracts from human trophoblast cells have been shown to suppress T-cell proliferation (Saji et al., 1989). Therefore, both the privileged status of the embryo from the maternal immune system and the lack of a local embryotoxic effect decrease the likelihood that immune components of luteal regression are candidates to be embryotoxic factors.

A systemic relationship between the regressing CL and the toxic effect it exerts on the embryo does not rule out $\mathrm{PGF}_{2 \alpha}$ as the embryotoxin. Although normally-timed luteolysis in ruminants is a local event, two-thirds of uterine $\mathrm{PGF}_{2 \alpha}$ reaches the ovary by the utero-ovarian blood and lymphatic vessels, while one-third of uterine $\mathrm{PGF}_{2 \alpha}$ reaches the CL by systemic 
circulation (Bonnin et al., 1999). Cooper et al. (1991) described elevated concentrations of $\mathrm{PGF}_{2 \alpha}$ in the vena caval blood (containing uterine and ovarian blood) of early postpartum cows on days 4 through 9 after the first ovulation. Prolonged secretion of $\mathrm{PGF}_{2 \alpha}$ (Cooper et al., 1991), the hypersensitivity of the endometrium to oxytocin (Zoller et al., 1989; Zollers et al., 1991; Zollers et al., 1993) and the hypersensitivity of CL to $\mathrm{PGF}_{2 \alpha}$ (Hu et al., 1990) in the early postpartum cow may result in a greater secretion of $\mathrm{PGF}_{2 \alpha}$ into the lumen of both uterine horns, resulting in a systemic action of uterine $\mathrm{PGF}_{2 \alpha}$.

The role of secretion of $\mathrm{PGF}_{2 \alpha}$ by the $\mathrm{CL}$ in luteal regression is emphasized further by changes in the ability of the CL to metabolize $\mathrm{PGF}_{2 \alpha}$ to PGFM, reflecting changes in activity of the enzyme prostaglandin dehydrogenase (PGDH; Silva, 2000). Luteal tissue collected from ewes early in the luteal phase had higher PGDH activity than CL from ewes in the late luteal phase. The $\mathrm{CL}$ of early postpartum cows may lack the ability to metabolize $\mathrm{PGF}_{2 \alpha}$ and therefore be more susceptible to uterine $\mathrm{PGF}_{2 \alpha}$ and consequently secrete more $\mathrm{PGF}_{2 \alpha}$.

Luteal phase deficiency is thought to be a major cause of unexplained infertility in humans. Inadequate gonadotropins during follicular development resulted in a corpus luteum that regressed 9 or 10 days after formation instead of the normal 13 days (Jones et al., 1976). The mechanism of luteal demise is different in primates and humans than in ruminants. The uterus is not necessary for luteal regression in humans (Keitler, 1904 as cited in Reynolds, 1949) or other primates (Burford and Diddle, 1936). Luteal regression is thought to be a self-contained event in which luteal prostaglandin inhibits the responsiveness of luteal cells to gonadotropins (Auletta et al., 1995). Progesterone replacement, although it is without effect in regard to embryonic survival 
in ruminants (Wiltbank et al., 1956; Diskin and Niswender, 1989), increased pregnancy rates in previously non-fertile humans (Jones et al., 1976; Soules et al., 1977; Check et al., 1990).

Two major luteal products during regression are $\mathrm{PGF}_{2 \alpha}$ and oxytocin. The half-life of oxytocin, although longer than $\mathrm{PGF}_{2 \alpha}$, is only 3 to 5 minutes (Fabian et al., 1969). Oxytocin was not elevated in early postpartum beef cows with short-lived CL during days 4 through 9 (Cooper et al., 1991), although PGFM and oxytocin were elevated together in dairy cows with short-lived CL (Peter et al., 1989). Therefore, oxytocin is a questionable candidate as a direct embryotoxin, although it may play an indirect role by increasing uterine secretion of $\mathrm{PGF}_{2 \alpha}$ (Lemaster et al., 1999).

Heat-stress has long been known to reduce fertility (Dutt et al., 1959). Embryonic mortality due to heat stress appears to be mediated by $\mathrm{PGF}_{2 \alpha}$. When cows were heat stressed between the period of estrous detection and artificial insemination, day-7 embryos were retarded in development and had a higher rate of abnormalities (Putney et al., 1989). Endometrial tissue from cows on day 17 incubated in high temperature secreted higher amounts of $\mathrm{PGF}_{2 \alpha}$ ( Putney et al., 1988; Malayer et al., 1990), while day-17 embryos incubated in high temperature secreted higher amounts of $\mathrm{PGE}_{2}$ (Putney et al., 1988). Embryos that were heat stressed had lower incorporation of amino acids and a lower production of proteins.

If the embryotoxic substance from the short-lived $\mathrm{CL}$ is $\mathrm{PGF}_{2 \alpha}$, than heightened $\mathrm{PGF}_{2 \alpha}$ may decrease the number of embryos per ewe even when complete luteal regression does not occur. It is not known what concentrations of $\mathrm{PGF}_{2 \alpha}$ are embryotoxic, and if these concentrations would be embryotoxic, but not luteolytic. Ewes bred out-of-season typically produce .2 to .8 fewer lambs per ewe lambing than ewes bred during the breeding season. 
Shelton and Morrow (1965) observed a larger disparity between ovulation rate and the number of lambs dropped in the beginning and end of the breeding season (September and June) compared to the mid-breeding season (December). It was hypothesized that this disparity between ovulation rate and number of lambs dropped was due to high environmental temperature. The percentage of fertilized embryos collected on day 3 was lower in ewes exposed to high environmental temperature for three days post-mating compared to ewes in normal temperatures (Alliston and Ulberg, 1961). These results indicate that part of the detrimental effect of heat occurs as the embryo is traveling down the oviduct. However, the transfer of embryos on day 3 from non-heat stressed ewes into heat stressed ewes also decreased embryonic survival, indicating that damage also occurs in the uterus. Learning the role of $\mathrm{PGF}_{2 \alpha}$ from the uterus, and perhaps from the $\mathrm{CL}$, in the problem of low prolificacy during out-of-season breeding may contribute to our understanding of early embryonic death.

If the regressing $\mathrm{CL}$ induced a systemic embryotoxic effect, it is expected that both embryos would be affected equally. However, treatment with $\mathrm{PGF}_{2 \alpha}$ resulted in the death of one embryo as frequently as it resulted in the death of both embryos. It appears that some individual embryos may be resistant to the embryotoxic effect independent of the location of the embryo in relation to the regressing CL. Embryos from cows that were heat stressed had lowered metabolism and lowered protein production, but it is not known if this was a cause or an effect of toxicity by $\mathrm{PGF}_{2 \alpha}$ or other compounds (Putney et al., 1988). Certainly, the metabolism and nutrient requirements of the pre-implantation embryo change during development (Brinster, 1971), as do the metabolism and secretions of the endometrium (Yochim, 1971). The effect of $\mathrm{PGF}_{2 \alpha}$ on the metabolism and secretory activity of the uterus is not known. 
In summary, the embryotoxic effect of an early-regressing CL in ewes supplemented with progesterone appears to be systemic in the ewe. $\mathrm{PGF}_{2 \alpha}$ is the most likely product of the corpus luteum that is responsible for embryonic mortality. Investigations into the timing of embryonic death and the threshold concentrations of $\mathrm{PGF}_{2 \alpha}$ required to cause embryonic death may yield information that would lead to the development of strategies that would improve reproductive efficiency during the early postpartum period in the cow and during out-of-season breeding in the ewe.

The timing of embryonic death is not clear. The changes that occur in the embryo have not been observed beyond day 6 until the time of ultrasonography at days 30 to 35, when the embryo was absent. In some ewes treated with $\mathrm{PGF}_{2 \alpha}$ in the present experiment, ultrasonography on day 25 revealed the presence of embryonic membranes and fluid, but no embryos. This finding allows for the possibility that that some of the embryos died at a later time than assumed or membrane development may have persisted beyond embryonic development. Although treatment of progestogen-supplemented cows with $\mathrm{PGF}_{2 \alpha}$ every eight hours on days 10 through 13 or 15 through 18 did not decrease pregnancy rate (Seals et al., 1999), the period of susceptibility may differ from the time of embryonic death. It would be beneficial to determine the timing and amount of exposure required to cause embryonic death. 


\section{LITERATURE CITED}

Alliston, C.W. and L.C. Ulberg. 1961. Early pregnancy loss in sheep at ambient temperatures of $70^{\circ}$ and $90^{\circ} \mathrm{F}$. as determined by embryo transfer. J. Anim. Sci. 20:608-613.

Anderson, L.L., R.L. Butcher, and R.M. Melampy. 1961. Subtotal hysterectomy and ovarian function in gilts. Proc. IV ${ }^{\text {th }}$ Internat. Cong. Animal Reprod. II: 329-331.

Anderson, L.L. 1977. Uterine control of ovarian function. In:R.M. Wynn (Ed.) Biology of the Uterus, (2 ${ }^{\text {nd }}$ edition) pp.587-651, Plenum Press, New York, NY.

Armstrong, D.T. and W. Hansel. 1959. Alteration of the bovine estrous cycle with oxytocin. J. Dairy Science 42:533-542.

Auletta, F.J., L.B. Kelm, and M.J. Schofield. 1995. Responsiveness of the corpus luteum of the rhesus monkey (Macaca mulatta) to gonadotrophin in vitro during spontaneous and prostaglandin $\mathrm{F}_{2 \alpha}$-induced luteolysis. J. Reprod. Fert. 103:107-113.

Barrett, S., M.A. De B. Blockey, J.M. Brown, I.A. Cumming, J.R. Goding, B.J. Mole, and J.M. Obst. 1971. Initiation of the oestrous cycle in the ewe by infusions of $\mathrm{PGF}_{2 \alpha}$ to the autotransplanted ovary. J. Reprod. Fert. 24:136-137.

Beal, W.E., R.A. Milvae, and W. Hansel. 1980. Oestrous cycle length and plasma progesterone concentrations following administration of prostaglandin $\mathrm{F}_{-2 a}$ early in the bovine oestrous cycle. J. Reprod. Fert. 59:393-396.

Bonney, R.C., S.T. Qizilbash, and S. Frank. 1987. Endometrial phospholipase $\mathrm{A}_{2}$ enzymes and their regulation by steroid hormones. J. Steroid. Biochem. 27:1057-1064. 
Bonnin, P., L. Huynh, R. L'Haridon, N. Chene, and J. Martal. 1999. Transport of uterine $\mathrm{PGF}_{2 \alpha}$ to the ovaries by systemic circulation and local lymphovenous-arterial diffusion during luteolysis in sheep. J. Reprod. Fert. 116:199-210.

Boyd, J.D., W.J. Hamilton, and J. Hammon, Jr. 1944. Transuterine ('internal') migration of the ovum in sheep and other mammals. J. Anat. 78:5-14.

Breuel, K.F., A. Fukuda, and F.N. Schrick. 1993. Effects of prostaglandin $F_{2 \alpha}$ on development of 8-cell rat embryos in vitro. Biol. Reprod. 48 (Suppl. 1): 173.

Breuel, K.F., P.E. Lewis, F.N. Schrick, A.W. Lishman, E.K. Inskeep, and R.L. Butcher. 1993. Factors affecting fertility in the postpartum cow: role of oocyte and follicle in conception rate. Biol. Reprod. 48:655-661.

Bridges, P.J., D.J. Wright, W.I. Buford, N. Ahmad, H. Hernandez-Fonseca, M.L. McCormick, F.N. Schrick, R.A. Dailey, P.E. Lewis, and E.K. Inskeep. 2000. Ability of induced corpora lutea to maintain pregnancy in beef cows. J. Anim. Sci. in press.

Brinster, R.L. 1971. Mammalian embryo metabolism. In R.J. Blandau (Ed.):The Biology of the Blastocyst. pp 303-318.. The University of Chicago Press. Chicago.

Buford, W.I., N. Ahmad, F.N. Schrick, R.L. Butcher, P.E. Lewis, and E.K. Inskeep. 1996. Embryotoxicity of a regressing corpus luteum in beef cows supplemented with progestogen. Biol. of Reprod. 54:531-537.

Burford, T.H. and A.W. Diddle. 1936. Effect of total hystectomy upon the ovary of the macacus rhesus. Surg. Gyn. Obst. 62:701-707. 
Check, J.H., J.S. Chase, and H.G. Adelson. 1990. Evidence for the existence of a pure corpus luteum deficiency. In: J.L.H Evers and M.J. Heineman (Ed.) From Ovulation to Implantation. pp 211-215. Elsevier Science Publishers B.V. Amsterdam, The Netherlands.

Clark, J. R., R.A. Dailey, R.B. Staigmiller, N.L. First, A.B. Chapman and L.E. Casida. 1975. Observed associations between corpora lutea and follicular development in swine ovaries during the estrous cycle. J. Anim. Sci. 41:1693-1699.

Cloud, J.G. and L.E. Casida. 1969. Local effect of the early sheep embryo upon uterine motility. J.Anim. Sci. 29:48-50.

Cooper, D.A., D.A. Carver, P. Villeneuve, W.J. Silvia, and E.K. Inskeep. 1991. Effects of progestagen treatment on concentrations of prostaglandins and oxytocin in plasma from the posterior vena cava of post-partum beef cows. Reprod. Fert. 91:411-421.

Copelin, J.P., M.F. Smith, H.A. Garverick, and R.S. Youngquist. 1987. Effect of the uterus on subnormal luteal function in anestrous beef cows. J. Anim. Sci. 64: 1506-1511.

Copelin, J.P., M.F. Smith, H.A. Garverick, R.S. Youngquist, W.R. McVey Jr., and E.K. Inskeep. 1988. Responsiveness of bovine corpora lutea to prostaglandin $\mathrm{F}_{2 \alpha}$ :comparison of corpora lutea anticipated to have short or normal lifespans. J. Anim. Sci. 66:1236-1245.

Copelin, J.P., M.F. Smith, D.H. Keisler, and H.A. Gaverick. 1989. Effect of active immunization of pre-partum and post-partum cows against prostaglandin F-2 $\alpha$ on lifespan and progesterone secretion of short-lived corpora lutea. J. Reprod. Fert. 87:199-207.

Croker, K.P, and J.N. Shelton. 1973. Influence of stage of cycle, progestagen treatment and dose of oestrogen on uterine motility in the ewe. J. Reprod. Fert. 32:521-524. 
Day, M.L., R.M. Dyer, G.W. Wilson, and W.F. Pope. 1990. Influence of estradiol on duration of anestrus and incidence of short estrous cycles in postpartum cows. Dom. Anim. Endo. $7: 19-25$.

Del Campo, C.H. and O.J. Ginther. 1973. Vascular anatomy of the uterus and ovaries and the unilateral luteolytic effect of the uterus: horses, sheep, and swine. Am. J. Vet. Res. $34: 305-316$.

Diehl, J.R. and B.N. Day, 1974. Effect of prostaglandin $F_{2 \alpha}$ on luteal function in swine. J. Anim. Sci. 39:392-396.

Dimov, V. and G. Georgiev. 1977. Ram semen prostaglandin concentration and its effect on fertility. J. Anim. Sci. 44:1050-1054.

Diskin, M.G. and G.D. Niswender. 1989. Effect of progesterone supplementation on pregnancy and embryo survival in ewes. J. Anim. Sci. 67: 1559-1563.

Dobrowolski, W. and E.S.E. Hafez. 1970. Ovariouterine vasculature in sheep. Am. J. Vet. Res. $31: 2121-2126$.

Douglas, R.H., and O.J. Ginther.1975a. Effects of prostaglandin $F_{2 \alpha}$ on estrous cycle or corpus luteum in mares and gilts. J. Anim. Sci. 40:518-522.

Dufour, J., O.J. Ginther, and L.E. Casida. 1971. Corpus luteum action on ovarian follicular development after destruction of macroscopically visible follicles in ewes. Proc. Soc. Exp. Biol. and Med. 138:475-478.

du Mesnil du Buisson, F., 1961. Possibilite d'un fonctionnement dissemblable des ovaries pendant la gestation chez la truie. C.R. Acad. Sci. Paris 253:727-729. 
Dutt, R.H., E.F. Ellington, and W.W. Carlton. 1959. Fertilization rate and early embryo survival in sheared and unsheared ewes following exposure to elevated air temperatures. J. Anim. Sci. 18:1308-1318.

Einspanier, R., A. Miyamoto, D. Schams, M. Muller, and G. Brem. 1990. Tissue concentration, mRNA expression and stimulation of IGF-I in luteal tissue during the oestrous cycle and pregnancy of cows. J. Reprod. Fert. 90:439-445.

Fabian, M., M.L. Forsling, J.J. Jones, and J.S. Pryor. 1969. The clearance and antidiuretic potenecy of neurohypophysial hormones in man, and their plasma binding and stability. J. Physiol. 204:653-6678.

Fairclough, R.J., L.G. Moore, L.T. McGowan, A.J. Peterson, J.F. Smith, H.R. Tervit, and W.B. Watkins. 1980. Temporal relationship between plasma concentrations of 13,14-dihydro15-keto-prostaglandin F and neurophysin I/II around luteolysis in sheep. Prostaglandins 20: 199-208.

Fairclough, R.J., L.G. Moore, A.J. Peterson, and W.B. Watkins. 1984. Effect of oxytocin on plasma concentrations of 13,14-dihydro-15-keto prostaglandin $\mathrm{F}$ and the oxytocinassociated neurophysin during the estrous cycle and early pregnancy in the ewe. Biol. of Reprod. 31:36-43.

Fields, P.A., R.K. Eldridge, A.R. Fuchs, R.F. Roberts, and M.J. Fields. 1983. Human placental and bovine corpora luteal oxytocin. Endocrinology 112:1544-1546.

Flint, A.P.F., W.M.F. Leat, E.L. Sheldrick, and H.J. Stewart. 1986. Stimulation of phosphoinositide hydrolysis by oxytocin and the mechanism by which oxytocin controls prostaglandin synthesis in the ovine endometrium. Biochem. J. 237:797-805. 
Fogwell, R.L., G.S. Lewis, R.L. Butcher, and E.K. Inskeep. 1977. Effects of ovarian bisection on response to intrafollicular injection of $\mathrm{PGF}_{2 \alpha}$ and on follicular development in ewes. J. Anim. Sci. 45:328-335.

Freidman, S., M. Gurevich, and M. Shemesh. 1995. Bovine cyclic endometrium contains highaffinity luteinizing hormone/ human chorionic gonadotropin binding sites. Biol. Reprod. 52:1020-1026.

Garcia-Winder, M., P.E. Lewis, E.C. Townsend, and E.K. Inskeep. 1987. Effects of norgestomet on follicular development in postpartum beef cows. J. Anim. Sci. 64:1099-1109.

Ginther, O.J., A.L. Pope, and L.E. Casida. 1966. Local effect of an intrauteruine plastic coil on the corpus luteum of the ewe. J. Anim. Sci. 25:472-475.

Ginther, O.J. 1967. Local utero-ovarian relationships. J. Anim. Sci. 26:578 - 585.

Ginther, O.J., C.O. Woody, S. Mahajan, K. Janakiraman, and L.E. Casida. 1967. Effect of oxytocin administration on the oestrous cycle of unilaterally hysterectomized heifers. J. Reprod. Fert. 14:225-229

Ginther, O.J. 1970. Effect of unilateral hysterectomy and separation or ligation of uterine horns on luteolytic action of intrauterine device in sheep. Am. J. Vet. Res. 31:2127-2130.

Ginther, O.J. 1976. Comparative anatomy of utero-ovarian vasculature. Veterinary Scope Vol. 10. The Upjohn Company. Kalamazoo, Michigan.

Ginther, O.J. 1981. Local versus systemic utero ovarian relationships in farm animals. Acta Vet. Scanda. Suppl. 77:103-115.

Hawk, H.W. 1968. Effect of intra-uterine devices on corpus luteum function. J. Anim. Sci. (Suppl. I) 27:119-128. 
Hawk, H.W. 1975. Hormonal control of changes in the direction of uterine contractions in the estrous ewe. Biol. of Reprod. 12:423430.

Heap, R.B., I.R. Fleet, and M. Hamon. 1985. Prostaglandin F-2 $\alpha$ is transferred from the uterus to the ovary in the sheep by lymphatic and blood vascular pathways. J. Reprod. Fert. 74:645656.

Hernandez-Fonseca, H.J., B.L. Sayre, R.L. Butcher, and E.K. Inskeep. 2000. Embryotoxic effects adjacent and opposite to the short-lived bovine corpus luteum. Theriogenology 54:83-91.

Hu, Y., J.D.H. Sanders, S.G. Kurz, J.S. Ottobre, and M.L. Day. 1990. In vitro prostaglandin production by bovine corpora lutea destined to be normal or short-lived. Biol. Reprod. 42:801-807.

Inskeep, E.K. and R.L. Butcher. 1966. Local component of utero-ovarian relationships in the ewe. J. Anim. Sci. 25: 1164-1168.

Jones, G.S. 1976. The luteal phase defect. Fertil. Steril. 27:351-356.

Keisler, D.H., E.K. Inskeep, and R.A. Dailey. 1983. First luteal tissue in ewe lambs: influence on subsequent ovarian activity and response to hysterectomy. J. Anim. Sci. 57:150-156.

Keitler, H. 1904. Uber das anatomische und funktionelle verhalten der belassenen ovarien nach exstirpation des uterus. Monatsch. f. Gebursh. Gynak. 20:686.

Kennedy, T.G. 1977. Evidence for a role for prostaglandins in the initiation of blastocyst implantation in the rat. Biol. Reprod. 16:286-291.

Knight, T.W., H.R. Tervit, and R.J. Fairclough. 1981. Corpus luteum function in ewes stimulated by rams. Theriogenology 15:183-189. 
Kotwica, J. and D. Skarzynski. 1993. Influence of oxytocin removal from the corpus luteum on secretory function and duration of the oestrous cycle in cattle. J. Reprod. Fert. 97:411417.

Land, R.B., D.T. Baird, and R.J. Scaramuzzi. 1976. Dynamic studies of prostaglandin-F ${ }_{2 \alpha}$ in the uteroovarian circulation of the sheep. J. Reprod. Fert. 47:209-214.

Lemaster, J.W., R.C. Seals, F.M. Hopkins, and F.N. Shrick. 1999. Effects of administration of oxytocin on embryonic survival in progestogen supplemented cattle. Prostaglandins $57: 259-268$.

Lewis, P.E., W.C. Taylor, and E.K. Inskeep. 1968. Exogenous progesterone on ovine corpora lutea. J. Anim. Sci 27:1193 (Abstract).

Ludwig, T.E., B. Sun, K.G. Carnahan, M. Uzumcu, J.V. Yelich, R.D. Geisert, and M.A. Mirando. 1998. Endometrial responsiveness to oxytocin during diestrus and early pregnancy in pigs is not controlled solely by changes in oxytocin receptor population density. Biol. Reprod. 58:769-777.

Lulai, C., I. Dobrinski, J.P. Kastelic, and R.J. Mapletoft. 1994. Induction of luteal regression, ovulation and development of new luteal tissue during early pregnancy in heifers. Anim. Reprod. Sci. 35:163-172.

Marshall, A.J. 1953. The unilateral endometrial reaction in the giant fruit-bat (pteropus giganteus brunnich). J. Endocrin. 9:42-44.

Malayer, J.R., P.J. Hansen, T.S. Gross, and W.W. Thatcher. 1990. Regulation of heat shockinduced alterations in the release of prostaglandins by the uterine endometrium of cows. Theriogenology 34:219-230. 
Maurer, R.R. and H.M. Beier. 1976. Uterine proteins and development in vitro of rabbit preimplantation embryos. J. Reprod. Fert. 48:33-41.

McArdle, C.A. and A.P. Holtorf. 1989. Oxytocin and progesterone release from bovine corpus luteal cells in culture: effects of insulin-like growth factor I, insulin, and prostglandins. Endocrinology 124:1278-1286.

McCracken, J.A., J.C.Carlson, M.E. Glew, J.R. Goding, D.T. Baird, K. Green, and B.

Samuelsson. 1972. Prostaglandin F-2 $\alpha$ identified as a luteolytic hormone in sheep. Nature, New Biol. 238:129-134.

McCracken, J.A. E.E. Custer, and J.C. Lamsa. 1999. Luteolysis: a neuroendocrine-mediated event. Physio. Reviews. 79:263-323.

McCracken, J.A., J.A. Amico, M.K. Newbury, and R.A. Milvae. 2000. Depletion of oxytocin from ovine corpus luteum does not extend cycle length. Biol. Reprod. 62 (Suppl. 1):142.

McDowell, K.J., D.C. Sharp, W. Grubaugh, W.W. Thatcher, and C.J. Wilcox. 1988. Restricted conceptus mobility results in failure of pregnancy maintenance in mares. Biol. Reprod. 39:340-348.

Milvae, R.A. and W. Hansel. 1985. Inhibition of bovine luteal function by indomethacin. J. Anim. Sci. 60:528-531.

Mirando, M.A., T.L. Ott, J.L. Vallet, M. Davis, and F.W. Bazer. 1990. Oxytocin-stimulated insoitol phosphate turnover in endometrium of ewes is influenced by stage of the estrous cycle, pregnancy, and intrauterine infusion of ovine conceptus secretory proteins. Biol. Reprod. 42:98-105. 
Moor, R.M. and L.E.A. Rowson. 1966. Local maintenance of the corpus luteum in sheep with embryos transferred to various isolated portions of the uterus. J. Reprod. Fert. 12:539550.

Moore, W.W. and A.V. Nalbandov. 1953. Neurogenic effects of uterine distention on the estrous cycle of the ewe. Endocrinology 53:1-11.

Mossman, H.W. and I. Judas. 1949. Accessory corpora lutea, lutein cell origin, and the ovarian cycle in the Canadian porcupine. Am. J. Anat. 85:1-39.

Newcomb, R., W.B. Christie, and L.E.A. Rowson. 1980. Fetal survival rate after the surgical transfer of two bovine embryos. J. Reprod. Fert. 59:31-36.

Niswender, G.D. and P.J. Dzuik. 1966. A study of the unilateral relationship between the embryo and the corpus luteum by egg transfer in the ewe. Anat. Rec. 154:394-395 (Abstr.).

Odde, K.G., H.S. Ward, G.H. Kiracofe, R.M. McKee, and R.J. Kittock. 1980. Short estrous cycles and associated serum progesterone levels in beef cows. Theriogenology 14:105112.

Ottobre, J.S., G.S. Lewis, W.V. Thayne, and E.K. Inskeep. 1980. Mechanism by which progesterone shortens the estrous cycle of the ewe. Biol. Reprod. 23:1046-1053.

Ottobre, J.S., D.L. Vincent, W.J. Silvia, and E.K. Inskeep. 1984. Aspects of regulation of uterine secretion of prostaglandins during the oestrous cycle and early pregnancy. Anim. Reprod. Sci. 7:75-100.

Palm, J., S. Heyner, and R.L. Brinster. 1971. Differential immunofluorescence of fertilized mouse eggs with H-2 and non-H-2 antibody. J. Exp. Med. 133:1282-1293. 
Pate, J.L. 1995. Involvement of immune cells in regulation of ovarian function. J. Reprod. Fert. Suppl. 49:365-377.

Peter, A.T., W.T.K. Bosu, R.M. Liptrap, and E. Cummings. 1989. Temporal changes in serum prostaglandin $\mathrm{F}_{2 \alpha}$ and oxytocin in dairy cows with short luteal phases after the first postpartum ovulation. Theriogenology 32:277-284.

Pexton, J.E., S.P. Ford, L. Wilson, Jr., R.L. Butcher, and E.K. Inskeep. 1975. Prostaglandins F in uterine tissue and venous plasma of ewes with intrauterine devices. J. Anim. Sci. 41:144153.

Putney, D.J., J.R. Malayer, T.S. Gross, W.W. Thatcher, P.J. Hansen, and M. Drost. 1988. Heat stress-induced alterations in the synthesis and secretion of proteins and prostaglandins by cultured bovine conceptuses and uterine endometrium. Biol. Reprod. 39:717-728.

Putney, D.J., S. Mullins, W.W. Thatcher, M. Drost, and T.S. Gross. 1989. Embryonic development in superovulated dairy cattle exposed to elevated ambient temperatures between the onset of estrus and insemination. Anim. Reprod. Sci. 19:37-51.

Ramirez-Godinez, J.A., G.H. Kiracofe, R.M. McKee, R.R. Schalles, and R.J. Kittok. 1981. Reducing the incidence of short estrous cycles in beef cows with norgestomet. Theriogenology. 15:613-623.

Reynolds, S.R.M. 1949. Effects of hysterectomy. In: Physiology of the Uterus. pp. 503-510. Paul B. Hoeber, Inc. New York, NY.

Rexroad, C.E., Jr. and L.E. Casida. 1975. Ovarian follicular development in cows, sows, and ewes in different stages of pregnancy as affected by number of corpora lutea in the same ovary. J. Anim. Sci. 41:1090-1097. 
Rexroad, C.E., Jr., 1981a. Estrogen and progestogen binding in the myometrium of the ewe. I. During the estrous cycle. J. Anim. Sci. 53:1057-1069.

Rexroad, C.E., Jr., 1981b. Estrogen and progestogen binding in the myometrium of the ewe. II. Regulation by estradiol and progesterone. J. Anim. Sci. 53:1070-1076.

Roberts, J.S., J.A. McCracken, J.E. Gavagan, and M.S. Soloff. 1976. Oxytocin-stimulated release of prostaglandin $\mathrm{F}_{2 \alpha}$ from ovine endometrium in vitro: correlation with estrous cycle and oxytocin-receptor binding. Endocrinology. 99:1107-1114.

Robinson, J.S., J.R.G. Challis, B.J.A. Furr, T.M. Louis, and G.D. Thorburn. 1976. Is the sheep corpus luteum subject to tonic inhibition during the luteal phase of the estrous cycle? Europ. J. Obstet. Gynec. Reprod. Biol. 6:191-199.

Rowson, L.E. 1955. The movement of radio opaque material in the bovine uterine tract. Br. Vet. J. 111:334-342.

Saji, F., T. Negoro, N. Matsuzaki, M. Koyama, T. Kameda, and O. Tanizawa. 1989. An immunoregulatory role of human trophoblasts. In: K. Yoshinaga and T. Mori (Ed.). Development of Preimplanation Embryos and Their Environment. pp 435-446.Alan R. Liss, Incl, New York, NY.

Sayre, B.L. 1995. Oxytocin-induced cervical dilation in sheep: mechanism of action and potential use for nonsurgical artificial insemination. PhD dissertation. Virginia Polytechnic and State University, Blacksburg, VA.

Sayre, B.L., R. Taft, E.K. Inskeep, and J. Killefer. 2000. Increased expression of insulin-like growth factor binding protein-1 during induced regression of bovine corpora lutea. Biol. Reprod. 63:21-29. 
Schallenberger, E., D. Schams, and H.H.D. Meyer. 1989. Sequences of pituitary, ovarian, and uterine hormone secretion during the first 5 weeks of pregnancy in dairy cattle. J. Reprod. Fert. (Suppl 37):277-286.

Schrick, F.N., E.K. Inskeep, and R. L. Butcher. 1993. Pregnancy rates for embryos transferred from early postpartum beef cows into recipients with normal estrous cycles. Biol. Reprod. 49:617-621.

Seals, R.C., J.W. Lemaster, F.M. Hopkins, and F.N. Schrick. 1999. Effects of elevated concentrations of prostaglandin F2 $\alpha$ on pregnancy rates in progestogen supplemented cattle. Prostaglandins \& other Lipid Mediators 56:377-389.

Sharma, S.C., and R.J. Fitzpatrick. 1974. Effect of oestradiol-17ß and oxytocin treatment on prostaglandin F alpha release in the anoestrous ewe. Prostaglandins 6:97-105.

Shelton, M. and J.T. Morrow. 1965. Effect of season on reproduction of rambouillet ewes. J. Anim. Sci. 24:795-799.

Shemesh, M., M. Gurevich, D. Mizrachi, L. Dombrovski, Y. Stram, M.J. Fields, and L.S. Shore. 1997. Expression of functional luteinizing hormone (LH) receptor and its messenger ribonucleic acid in bovine uterine veins: LH induction of cyclooxygenase and augmentation of prostaglandin production in bovine uterine veins. Biol. Reprod. 138:4844-4851.

Silva, P.J., J.L. Juengel, A.M. Turzillo, M.K. Rollyson, F. Diaz, M.C. Wiltbank, and G.D. Niswender. 2000. Prostaglandin metabolism in the ovine corpus luteum: catabolism of prostaglandin $\mathrm{F}_{2 \alpha}\left(\mathrm{PGF}_{2 \alpha}\right)$ coincides with resistance of the corpus luteum to $\mathrm{PGF}_{2 \alpha}$. In press. 
Soules, M.R., R.H. Wiebe, S. Aksel, C.B. Hammond. 1977. The diagnosis and therapy of luteal phase deficiency. Fertil. Steril. 28:1033-1037.

Tsai, S. and M.C. Wiltbank. 1998. Prostaglandin $\mathrm{F}_{2 \alpha}$ regulates distinct physiological changes in early and mid-cycle bovine corpora lutea. Biol. Reprod. 58:346-352.

Vincent, D.L. and E.K. Inskeep. 1986. Role of progesterone in regulating uteroovarian venous concentrations of $\mathrm{PGF}_{2 \alpha}$ and $\mathrm{PGE}_{2}$ during the estrous cycle and early pregnancy in ewes. Prostaglandins 31:715-733.

Viring, S., S. Einarsson, B. Jones, and K. Larsson. 1980. Transuterine transport of small- and medium-sized molecules deposited in the uterus in gilts. J. Reprod. Fert. 59:459-462.

Voss, A.K. and J.E. Fortune. 1992. Oxytocin/neurophysin-1 messenger ribonucleic acid in bovine granulosa cells increases after the luteinizing hormone (LH) surge and is stimulated by LH in vitro. Endocrinology 131:2755-2762.

Ward, H.S., K.G. Odde, G.H. Kiracofe, and R.M. McKee. 1979. Short estrous cycles after weaning in anestrous beef cows. J. Anim. Sci. 49(suppl. 1):345.

Wathes, D.C. and R.W. Swann. 1982. Is oxytocin an ovarian hormone? Nature 297:225-227.

Watson, A.J., A. Hogan, A. Hahnel, K.E. Wiemer, and G.A. Schultz. 1992. Expression of growth factor ligand and receptor genes in the preimplantation bovine embryo. Mol. Reprod. Dev. $31: 87-95$.

Weems, C.W., Y.S. Weems, C.N. Lee, and D.L. Vincent. 1989. Progesterone in uterine and arterial tissue and in jugular and uterine venous plasma of sheep. Biol. Reprod. 41:1-6. 
Weems, Y.S., P.J. Bridges, Y. Tanaka, R.G. Sasser, B.R. LeaMaster, D.L. Vincent, and C.W. Weems. 1997. $\mathrm{PGE}_{1}$ or $\mathrm{PGE}_{2}$, not $\mathrm{LH}$ regulates secretion of progesterone in vitro by the 88-90 day ovine corpus luteum of pregnancy. Prostaglandins 53:337-353.

Wiltbank, J.N., H.W. Hawk, H.E. Kidder, W.G. Black, L.C. Ulberg, and L.E. Casida. 1956. Effect of progesterone therapy on embryo survival in cows of lowered fertility. J. Dairy Science 39: 456-461.

Wiltbank, M.C., T.F. Shiao, D.R. Bergfelt, and O.J. Ginther. 1995. Prostaglandin F2 $\alpha$ receptors in the early bovine corpus luteum. Biol. Reprod. 52: 74-78.

Wright, D.J., W.I. Buford, F.N. Schrick, and E.K. Inskeep. 1994. Ability of induced secondary corpora lutea to maintain pregnancy in beef cows. J. Anim. Sci. (Suppl.2):125 (Abst.).

Yochim, J.M. 1971. Intrauterine oxygen tension and metabolism of the endometrium during the preimplantation period. In R.J. Blandau (Ed.):The Biology of the Blastocyst. pp 363-382. The University of Chicago Press. Chicago.

Zollers, W.G., Jr., H.A. Garverick, and M.F. Smith. 1989. Oxytocin-induced release of prostaglandin F2 $\alpha$ in postpartum beef cows: comparison of short versus normal luteal phases. Biol. Reprod. 41:262-267.

Zollers, W.G., Jr., H.A. Garverick, R.S. Youngquist. J.S. Ottobre. R.W. Silcox, J.P. Copelin, and M.F. Smith. 1991. In vitro secretion of prostaglandins from endometrium of postpartum beef cows expected to have short or normal luteal phase. Biol. Reprod. 44:522-526.

Zollers, W.G., Jr., H.A. Garverick, M.F. Smith, R.J. Moffatt, B.E. Salfen, and R.S. Youngquist. 1993. Concentrations of progesterone and oxytocin receptors in endometrium of 
postpartum cows expected to have a short or normal oestrous cycle. J. Reprod. Fert.

97:329-337. 
VITA

Beth Alyson Costine

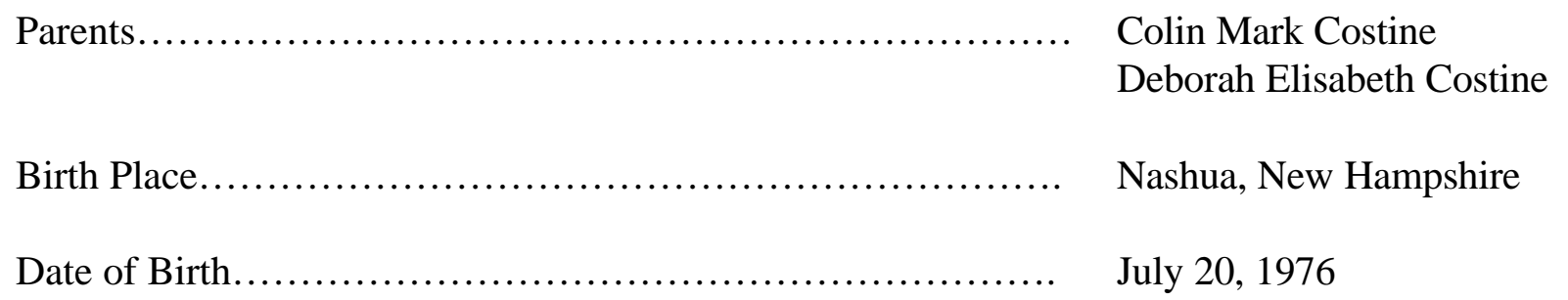

Schools Attended:

Calvary Christian School............................ 1982-1994

Derry, New Hampshire

Virginia Polytechnic and State University............... 1994-1998

Blacksburg, Virginia

West Virginia University............................ 1998-

Morgantown, West Virginia

Degrees Conferred:

Bachelor of Science in Animal and Poultry Science........ 1998

Virginia Polytechnic and State University, Blacksburg, VA 